Thermoanalytical investigation of the reactions causing the transuranic waste drum breach that occurred in the Waste Isolation Pilot Plant

Randall D. Scheele ${ }^{\mathrm{a}}$ (corresponding author)

Email: randall.scheele@pnnl.gov

PO Box 999, Battelle Blvd, MSIN P7-25

Richland, WA 99352

Bruce K. McNamara $^{a}$

Email: bruce.mcnamara@pnnl.gov

Jon M. Schwantes ${ }^{\mathrm{a}}$

Email: jon.schwantes@pnnl.gov

David T. Hobbs ${ }^{\mathrm{b}}$

Email: david.hobbs@srnl.doe.gov

Michael J. Minette ${ }^{\mathrm{a}}$

Email: michael.minette@pnnl.gov

Christopher A. Barrett ${ }^{\mathrm{a}}$

Email: christopher.barrett@pnnl.gov

Pacific Northwest National Laboratory ${ }^{\mathrm{a}}$

PO Box 999, Battelle Blvd

Richland, Washington 99352

United States of America

Savannah River National Laboratory ${ }^{\mathrm{b}}$

Savannah River Site, Aiken, SC 29808 


\section{Abstract: ${ }^{1}$}

In February 2014, an energetic gas-producing chemical reaction occurred in remediated plutonium processing waste emplaced in the Waste Isolation Pilot Plant causing the drum's seal to fail and release radioactive material into and outside of the plant. This article provides results of our probative study using simultaneous thermogravimetric and differential thermal analysis and accelerating rate calorimetry to determine the thermal sensitivities of selected simulated characteristic remediated wastes such as hydrogen- and hydrogen, metaltriethanolamine nitrates and nitric acid solidified and stabilized with wheat-based pet litter. These studies found that these nitrate wastes were chemically unstable and susceptible to gasproducing thermal runaway reactions. If undried or partially dried, self-sustaining or accelerating-exothermic reactions were delayed in nitrate- and organic-containing materials to above $100^{\circ} \mathrm{C}$ while air-dried nitric acid and pet litter began self-heating exothermic reactions near $30^{\circ} \mathrm{C}$ that led to thermal runaway. Caution must be exercised when managing nitratecontaining wastes.

Keywords: Waste Reactivity; Solidification and Stabilization; Plutonium Waste Management; Inorganic Nitrate Waste; Triethanolamine; Waste Isolation Pilot Plant drum breach; Nitrate-Organic Reactivity

\section{Introduction}

On February 14, 2014, a transuranic (TRU) waste drum emplaced in the salt mine at the Waste Isolation Pilot Plant (WIPP) near Carlsbad, New Mexico, breached due to an internal chemical reaction [1]; Figure 1 provides a picture of the breached drum. The breach released radioactive material internal and external to WIPP. The breach occurred 72 days after the TRU waste drum was generated by Los Alamos National

\footnotetext{
${ }^{1}$ Abbreviations: accelerating rate calorimeter (ARC), Center for Chemical Process Safety (CCPS), Spilfyter ${ }^{\circledR}$ Kolorsafe $^{\circledR}$ Acid Neutralizer (Kolorsafe), metal (M), melting point (mp), ambient relative humidity (RH), sWheat Scoop ${ }^{\circledR}$ (sWheat), triethanolamine (TEA), triethanolamine nitrate (TEAN), thermogravimetric and differential thermal analyzer (TG/DTA), transuranic (TRU), Waste Isolation Pilot Plant (WIPP).
} 
Laboratory and 16 days after the drum was emplaced in Room 7 of Panel 7 of WIPP [2].

Unfortunately, the WIPP event was not unique for TRU wastes. In 2003 a fire occurred in a glovebox containing ceric nitrate/nitric acid/cloth decontamination wastes at the Rocky Flats Environmental Site [3, 4]. Because of the Rocky Flats fire, management at the Plutonium Finishing Plant on the U.S. Department of Energy (DOE) Hanford Site developed a plan for managing the nitrate-containing wastes that would arise from decontamination of its plutonium-contaminated gloveboxes based on experimental studies to determine the thermal stabilities of wastes arising from the candidate decontamination methods [5-9].

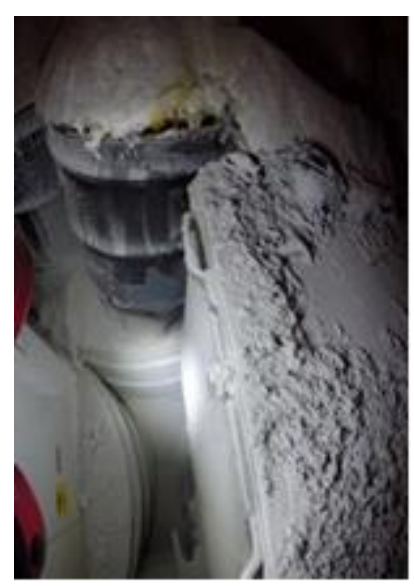

\section{Figure 1. WIPP drum after breach}

The TRU waste in the breached drum originated from plutonium recovery and purification operations at Los Alamos National Laboratory. The acidic residues from plutonium processing were evaporated and cooled to produce crystalline salts, which were collected, briefly rinsed with nitric acid, placed in plastic bags, and stored for about 30 years in lead-lined steel drums. After storage, Los Alamos National Laboratory 1) retrieved and opened the drums; 2) decanted, neutralized, and absorbed any separated free liquid; and 3) recovered and mixed the moist solids with an absorbent to sorb any interstitial liquid. The remediated waste was then placed into 
TRU waste drums and sent to WIPP. The breached drum contained both remediated salt and liquid wastes.

During the campaign to remediate the wastes, the recovered nitrate salt and nitric acid solution was neutralized with Spilfyter ${ }^{\circledR}$ Kolorsafe $^{\circledR}$ Acid Neutralizer [10], which is an aqueous triethanolamine (TEA) solution with alizarin $\mathrm{pH}$ indicator, and then solidified using the wheat-based pet litter unscented sWheat Scoop ${ }^{\circledR}$ (sWheat) [11]. The remaining nitrate salt portion was then treated with sWheat to absorb the interstitial acidic nitric acid/nitrate salt solution.

Treatment of the decanted acidic nitrate salt solution with the Lewis base TEA produced hydrogen triethanolamine nitrate (HTEAN) and mixtures of hydrogen and metal triethanolamine nitrate complexes $(\mathrm{H}, \mathrm{M}) \mathrm{TEAN}$. TEA is a mildly alkaline $[12$, 13], polyfunctional ligand capable of bonding through its nitrogen and/or oxygen atoms to form complexes with Lewis acids including metal ions [14-16] to form nitrate salts (TEAN). The use of TEA to neutralize the acid added to the chemical complexity of the remediated waste by increasing the fuel loading and adding thermally sensitive reactive compounds composed of both an oxidant and fuel.

The TRU waste in the breached drum was a complex mixture of nitric acid, various metal nitrate salts, hydrogen and metallic ion TEA nitrates, and sWheat. This combination of oxidizing nitrate salt residues, organic sorbent, and neutralizing agent formed potentially incompatible reactive chemical mixtures based on guidance from the Center for Chemical Process Safety (CCPS) of the American Institute of Chemical Engineers $[17,18]$.

Other waste added to the drum included glovebox refuse, such as plastic bags and empty plastic bottles, and a glovebox glove reported to be lined with a mixture of bismuth, tungsten, and lanthanum. Clark and Funk [19] and Wilson et. al. [1] provide 
detailed, in-depth descriptions of the original and remediated wastes that were put into the drum that breached.

To determine to the feasibility the particular mechanism(s) and chemical reactions that caused the waste drum to breach and release radioactive material into and outside of WIPP [2], the U.S. Department of Energy (DOE) assembled the WIPP Technical Advisory Team (TAT) [1] from selected national laboratories.

This article provides results from our probative set of thermoanalytical experiments performed in support of the Technical Advisory Team's assessment to identify the internal waste reaction(s) that under WIPP conditions could have led to the drum breach and radionuclides release. Using CCPS recommendations $[17,18]$ and our previous experience investigating reaction thermal sensitivities of 1) cellulose and different nitrate salt mixtures $[5,6,8,20,21]$ and 2) amine-based complexants and nitrate mixtures [22] as our investigative foundation, we used simultaneous thermogravimetric and differential thermal analysis (TG/DTA) and accelerating rate calorimetry (ARC) to determine the thermal sensitivities of a selected set of waste constituents, simulated remediation products, and simulated remediation wastes. The simulant compositions were based on the multi-component composition of the mixture of the original Los Alamos liquid and salt TRU waste, remedial additives, and other materials that were put into the drum.

\section{Experimental}

Using concentration estimates from Wilson et al. [1] and Clark and Funk [23], and based on our own experience during testing with required sWheat treatment levels, the individual waste constituents and partially simulated wastes tested were

- sWheat,

- 1 volume part 3.5 $\mathrm{M} \mathrm{HNO}_{3}$ and 3 volume parts sWheat mixtures, 
- HTEAN, $(\mathrm{H}, \mathrm{Pb}) \mathrm{TEAN}$, and $(\mathrm{H}, \mathrm{Pb}, \mathrm{Fe}) \mathrm{TEAN}$ complex salts produced from neutralization with TEA to $\mathrm{pH}$ paper-measured $\mathrm{pH} 7$ of nitric acid and nitric acid solutions saturated with lead and iron nitrates, and

- HTEAN, $(\mathrm{H}, \mathrm{Pb}) \mathrm{TEAN}$, and $(\mathrm{H}, \mathrm{Pb}, \mathrm{Fe}) \mathrm{TEAN}$ solutions and salts mixed with sWheat.

A significant challenge for determining the thermal stabilities and sensitivities of wastes arising from aqueous processes is accurately determining the water or volatiles content as a function of time after assembly, given the design of the drum and susceptibility of the plastics used to contain the remediated wastes. A TRU waste drum is passively ventilated through a NucFil ${ }^{\circledR}$ filter [24] to ensure that hydrogen and other gases generated by radiolysis do not accumulate and create a hydrogen explosion or drum pressurization hazard. Our prior experience with TRU cloth decontamination wastes from Hanford's Plutonium Finishing Plant indicates that any water disposed in horse-tailed vented robust polyvinyl chloride plastic bags would evaporate, leaving dry waste. Water is particularly important because of its substantial heat capacity $\left(C_{p}=4.179 \mathrm{~J} \mathrm{~g}^{-1}{ }^{\circ} \mathrm{C}^{-1}\right.$ at $\left.298^{\circ} \mathrm{C}\right)$ and heat of evaporation $\left(2.27 \mathrm{~kJ} \mathrm{~g}^{-1}\right)$ [25] between room temperature and $100^{\circ} \mathrm{C}$, which will significantly influence whether exothermic reactions can self-propagate to ignition or thermal runaway. To assess the importance of water, we also evaluated the thermal reactivity of mixtures having reduced water content by using a variety of drying approaches, which are described in the preparation and results sections. It should be noted that the salt mine's desiccating qualities could contribute to drying the waste.

\subsection{Instruments}

A Seiko 5200 TG/DTA was used. The TG/DTA was temperature calibrated using melting point $(\mathrm{mp})$ standards of $99.999 \%$ pure $\mathrm{In}\left(\mathrm{mp} 156.6^{\circ} \mathrm{C}\right), \mathrm{Sn}\left(\mathrm{mp} 231.9^{\circ} \mathrm{C}\right), \mathrm{Zn}$ 
( $\left.\mathrm{mp} 419.6^{\circ} \mathrm{C}\right)$, and $99.995 \% \mathrm{~Pb}\left(\mathrm{mp} 327.5^{\circ} \mathrm{C}\right)$, and the instrument's four-point polynomial temperature calibration fit. The resulting calibration yielded a measured In $\mathrm{mp}$ of $155^{\circ} \mathrm{C}$ and $\mathrm{Pb} \mathrm{mp}$ of $332^{\circ} \mathrm{C}$. In general, the DTA results were baselinecorrected by the instrument. No mass calibration was performed, so TG results are reported as percentage of reported initial mass. The TG/DTA experiments typically used a heating rate of $5^{\circ} \mathrm{C} / \mathrm{min}$, either open aluminum or gold sample pans, and either static room air or an ultra-high purity Ar purge. The TG/DTA was located in a fume hood on a massive marble slab to minimize disruptive vibrations.

We used a Thermal Hazard Technology ARC, an adiabatic calorimeter that measures exothermic-reaction-driven sample self-heating $[26,27]$ up to $15^{\circ} \mathrm{C} / \mathrm{min}$; heating rates above $15^{\circ} \mathrm{C} / \mathrm{min}$ underestimate the true rate. We used $2.5-$ to 8 -g samples in 9.5-mL nominal 8.5-g titanium spherical sample containers capable of containing $20 \mathrm{MPa}$ (200 bar). The ARC was calibrated through a single run with an empty sample container to ensure that the thermocouples reported equivalent temperatures. After calibration, the ARC's temperature drift was measured in one or more runs.

We operated the ARC in a heat/wait/search mode using a $>0.01^{\circ} \mathrm{C} / \mathrm{min}$ selfheating exotherm criterion with the sample thermocouple located on the container's bottom pole. If the ARC does not observe an exothermic reaction, the instrument does not report any self-heating or pressure data, which for these tests led to gaps between non-sustainable exotherms.

Because of the test material's changing chemical and physical nature as the reaction(s) proceeds, we report the measured self-heat rate rather than adjusting the self-heat rate for the sample container's thermal inertia using the initial $\Phi$-factor provided in Equation 1 [17]. The $C_{p}$ values that could be used to calculate the initial 
$\Phi$-factor are $3.289 \mathrm{~J} \mathrm{~g}^{-1}{ }^{\circ} \mathrm{C}^{-1}[28]$ for $3.5 \mathrm{M} \mathrm{HNO}_{3}$ and its TEA-neutralized solutions, $0.524 \mathrm{~J} \mathrm{~g}^{-1}{ }^{\circ} \mathrm{C}^{-1}$ [25] for the titanium bomb, and $1.63 \mathrm{~J} \mathrm{~g}^{-1}{ }^{\circ} \mathrm{C}^{-1}$ [29] for sWheat. provides the sample compositions and initial $\Phi$-factor used for ARC testing, assuming that any mass loss during drying was simply water.

$$
\Phi=1+\left(C_{p(\text { bomb })} \times m_{\text {bomb }}\right) /\left(C_{p(\text { sample })} \times m_{\text {sample }}\right)[17]
$$

Table I. Samples used in ARC Testing

\begin{tabular}{|l|l|l|l|l|l|l|l|}
\hline \multicolumn{1}{|c|}{ Sample } & Figure & $\begin{array}{c}\text { Sample } \\
3.5 \mathrm{M} \\
\mathrm{HNO}_{3}, \mathrm{~g}\end{array}$ & $\begin{array}{c}(\mathrm{H}, \mathrm{M}) \mathrm{TEAN}, \\
\mathrm{g}\end{array}$ & $\begin{array}{c}\text { sWheat, } \\
\mathrm{g}\end{array}$ & $\begin{array}{c}\text { Ti } \\
\text { Bomb, } \\
\mathrm{g}\end{array}$ & $\begin{array}{c}\text { Sample } \\
\text { Mass, } \\
\mathrm{g}\end{array}$ & $\begin{array}{c}\text { Initial } \\
\Phi- \\
\text { Factor }\end{array}$ \\
\hline $\begin{array}{l}\text { Undried } \\
\mathrm{HNO}_{3} / \mathrm{sWheat}\end{array}$ & Figure 6 & 1.136 & $\mathrm{NA}$ & 1.6656 & 8.5026 & 2.7855 & 1.696 \\
\hline $\begin{array}{l}\text { 7-Day Dried } \\
\mathrm{HNO}_{3} / \mathrm{sWheat}\end{array}$ & Figure 7 & 1.0483 & $\mathrm{NA}$ & 5.9113 & 8.4908 & 6.9596 & 1.340 \\
\hline $\begin{array}{l}\text { Semi-dried } \\
(\mathrm{H}, \mathrm{Pb}, \mathrm{Fe} \text { )TEAN }\end{array}$ & Figure 12 & NA & 3.3538 & NA & 8.4411 & 3.3538 & 1.39 \\
\hline $\begin{array}{l}\text { Undried } \\
\text { HTEAN/sWheat }\end{array}$ & Figure 14 & NA & 1.124 & 1.654 & 8.4411 & 2.778 & 1.692 \\
\hline $\begin{array}{l}\text { Undried } \\
\text { (H,Pb)TEAN/sWh } \\
\text { eat }\end{array}$ & Figure 15 & NA & 1.1133 & 1.6722 & 8.5232 & 2.7855 & 1.699 \\
\hline $\begin{array}{l}\text { Dried } \\
(\mathrm{H}, \mathrm{Pb}, F e) T E A N / s \\
\text { Wheat }\end{array}$ & Figure 17 & NA & 3.3653 & 5.6349 & 8.5 & 9.0002 & 1.220 \\
\hline
\end{tabular}

\section{2. $\quad$ Materials}

The TEA used was Kolorsafe, supplied by NPS Corporation (Lot \#14230).

Kolorsafe is a $\mathrm{pH} 10.2$ aqueous solution containing 52.954 wt\% TEA (3.87 M TEA) and a $\mathrm{pH}$ indicator alizarin $[10,30]$. Pet Care Systems, Inc. produced the sWheat, which was derived from the whole grain of wheat $[11,31]$. The $3.5 \mathrm{M} \mathrm{HNO}_{3}$ was prepared from Fisher Scientific trace metal grade concentrated $\mathrm{HNO}_{3}$ (Lot \#111302) and deionized water. The $\mathrm{Pb}\left(\mathrm{NO}_{3}\right)_{2}$ used to prepare the $\mathrm{Pb}\left(\mathrm{NO}_{3}\right)_{2}$-saturated $3.5 \mathrm{M}$ $\mathrm{HNO}_{3}$ was Baker Analyzed ACS reagent grade (Lot \#82050); based on Ferris [32], the saturated $\left[\mathrm{Pb}\left(\mathrm{NO}_{3}\right)_{2}\right]$ concentration in $3.5 \mathrm{M} \mathrm{HNO}_{3}$ is $0.3 \mathrm{M}$. The combination $\mathrm{Pb}\left(\mathrm{NO}_{3}\right)_{2}$ - and $\mathrm{Fe}$-saturated $\mathrm{HNO}_{3}$ solution was prepared by treating Johnson Matthey 
Electronics grade 99.2\%, -48 mesh iron metal (Fe) powder (Lot \#F17B15) with the prepared $\mathrm{Pb}\left(\mathrm{NO}_{3}\right)_{2}$-saturated 3.5 $\mathrm{M} \mathrm{HNO}_{3}$.

\subsubsection{Preparation of Simulated Waste Solutions and TEANs}

We prepared the tested simulated remediated liquid waste components by neutralizing solutions of $3.5 \mathrm{M} \mathrm{HNO}_{3}, \mathrm{~Pb}\left(\mathrm{NO}_{3}\right)_{2}$-saturated $3.5 \mathrm{M} \mathrm{HNO}_{3}$, and $\mathrm{Pb}\left(\mathrm{NO}_{3}\right)_{2}$ - and $\mathrm{Fe}$-saturated $\mathrm{HNO}_{3}$ to $\mathrm{pH} 7$ with TEA to prepare solutions or slurries of HTEAN, $(\mathrm{H}, \mathrm{Pb})$ TEAN, and $(\mathrm{H}, \mathrm{Pb}, \mathrm{Fe}) \mathrm{TEAN}$. The $\mathrm{pH}$ was determined with $\mathrm{pH}$ paper. Neutralization produced solutions from 3.5 $\mathrm{M} \mathrm{HNO}_{3}$ and $\mathrm{Pb}$-saturated $\mathrm{HNO}_{3}$, and solids from the $(\mathrm{Pb}, \mathrm{Fe})$-saturated $\mathrm{HNO}_{3}$.

To determine the amount of TEA required for neutralization, the solutions of 3.5 $\mathrm{M} \mathrm{HNO}_{3}$ and $\mathrm{Pb}\left(\mathrm{NO}_{3}\right)_{2}$-saturated $3.5 \mathrm{M} \mathrm{HNO}_{3}$ were titrated with TEA. The $3.5 \mathrm{M}$ $\mathrm{HNO}_{3}$ had an equivalence point at approximately $\mathrm{pH} 4$, indicating a concentration of the active TEA ingredient of $3.1 \mathrm{meq} / \mathrm{mL}$ Kolorsafe compared to NPS's reported 3.8 M TEA [30]. The $\mathrm{Pb}\left(\mathrm{NO}_{3}\right)_{2}$-saturated $\mathrm{HNO}_{3}$ had only two equivalence points, one at $\mathrm{pH} 2.5$ and the other at $\mathrm{pH}$ 5.5. Since achieving $\mathrm{pH} 7$ requires additional TEA after equivalence, the neutralized liquid wastes would be expected to contain HTEAN, $(\mathrm{H}, \mathrm{M}) \mathrm{TEAN}$, and free TEA.

\subsubsection{Preparation of sWheat Mixtures}

To prepare the sWheat mixtures, 3 volumes of sWheat were mixed with 1 volume of the Kolorsafe-neutralized solutions [19], unneutralized 3.5 $\mathrm{M} \mathrm{HNO}_{3}$, and $(\mathrm{H}, \mathrm{Pb})\left(\mathrm{NO}_{3}\right)_{4.1}$ to produce the five mixtures: 1) HTEAN/sWheat, 2) ( $\mathrm{H}, \mathrm{Pb}) \mathrm{TEAN} / \mathrm{sWheat}, 3)(\mathrm{H}, \mathrm{Pb}, \mathrm{Fe}) \mathrm{TEAN} / \mathrm{sWheat}$, 4) $3.5 \mathrm{M} \mathrm{HNO}_{3} / \mathrm{sWheat}$, and 5) $(\mathrm{H}, \mathrm{Pb}) \mathrm{NO}_{3} / \mathrm{sWheat}$. The latter two simulate the waste that would arise as a result of residual interstitial liquids in the salt fraction. Early testing of TEA-neutralized 
surrogate liquid wastes used as-received sWheat and later testing used sWheat ground with a bladed electric coffee grinder (Figure 2).

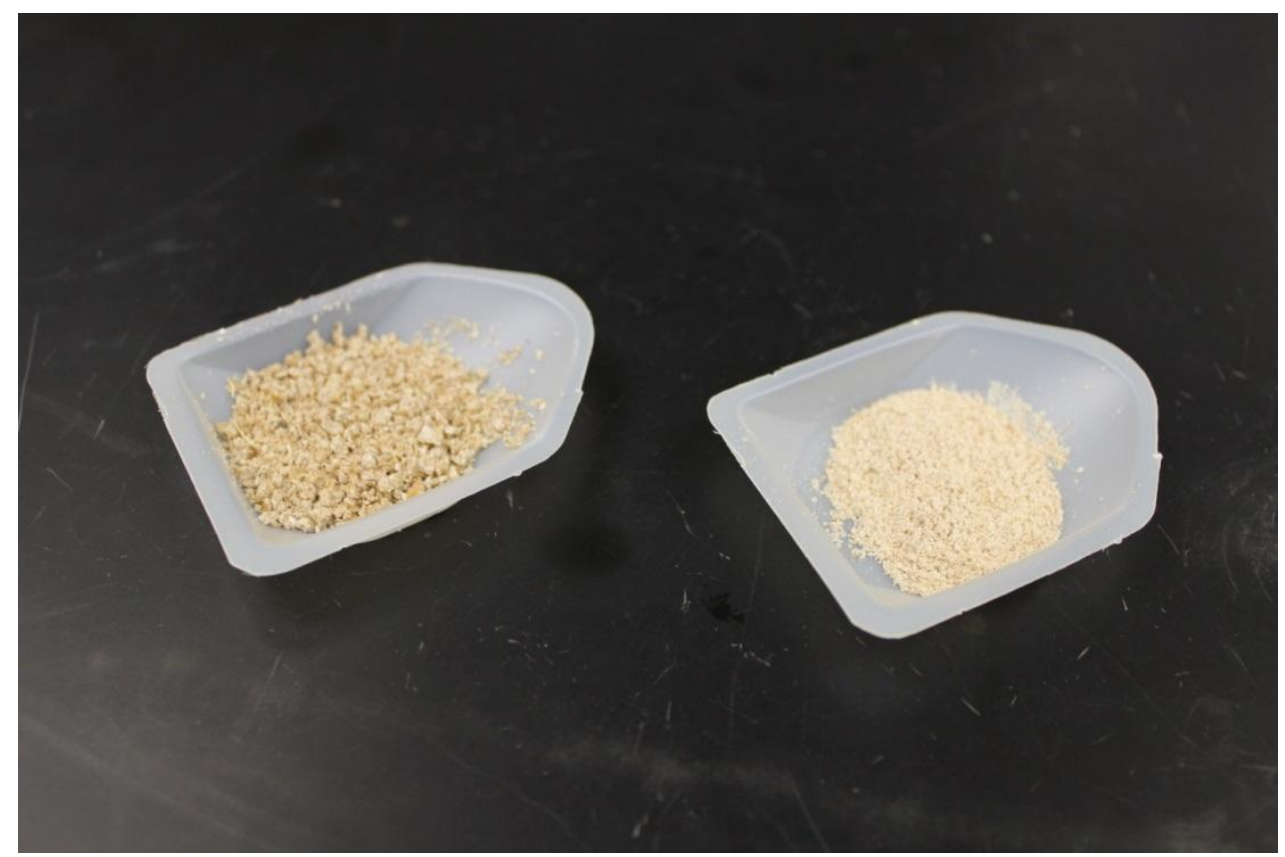

\section{Figure 2. Picture of as-received (left) and ground sWheat (right)}

We used a variety of methods to prepare and dry the sWheat and liquid mixtures.

Initially, the test mixtures were prepared inside the sample container. For the TG/DTA testing, the sample was dried at room temperature in flowing dry Ar. The method for drying the ARC samples evolved, starting with drying in the small diameter necked sample container using vacuum or Ar atmospheres and/or elevated temperature combinations.

Simple passive air drying in the laboratory at room temperature at ambient relative humidities (RHs) proved to be most effective at producing a final water content low enough to not quench room-temperature self-accelerating reactions. The $3.5 \mathrm{M}$ $\mathrm{HNO}_{3} / \mathrm{sWheat}$ composed of $33.8 \% \mathrm{H}_{2} \mathrm{O}, 7.6 \% \mathrm{HNO}_{3}$, and $59.6 \%$ sWheat lost $30 \%$ of its mass after 7 days of sitting in a laboratory at room temperature $\left(16^{\circ} \mathrm{C}\right.$ to $\left.18.5^{\circ} \mathrm{C}\right)$ at RHs ranging from $10 \%$ to $15 \%$. Assuming no evaporation or reaction between the $\mathrm{HNO}_{3}$ and sWheat, the $30 \%$ mass loss translated to $90 \% \mathrm{H}_{2} \mathrm{O}$ evaporation. With the 
high water loss, the residual liquid in the sWheat should be highly concentrated in $\mathrm{HNO}_{3}$.

Passive air-drying caused the freshly wetted $3.5 \mathrm{M} \mathrm{HNO}_{3} / \mathrm{sWheat}$ mixture to shrink, compact, and produce an orange, very hard, non-friable material, as shown in Figure 3. The strong orange color suggests reaction between sWheat and $\mathrm{HNO}_{3}$. In comparison, $(\mathrm{H}, \mathrm{Pb}, \mathrm{Fe}) \mathrm{TEAN} / \mathrm{sWheat}$ similarly dried at $10 \%$ to $21 \% \mathrm{RHs}$ dried to its equilibrium water content in about $80 \mathrm{~h}$. These two sWheat drying profiles indicate that when fully exposed at room temperature to RHs ranging from $10 \%$ to $20 \%$, waste/sWheat mixtures would dry to their equilibrium liquid content in 3 to 10 days.

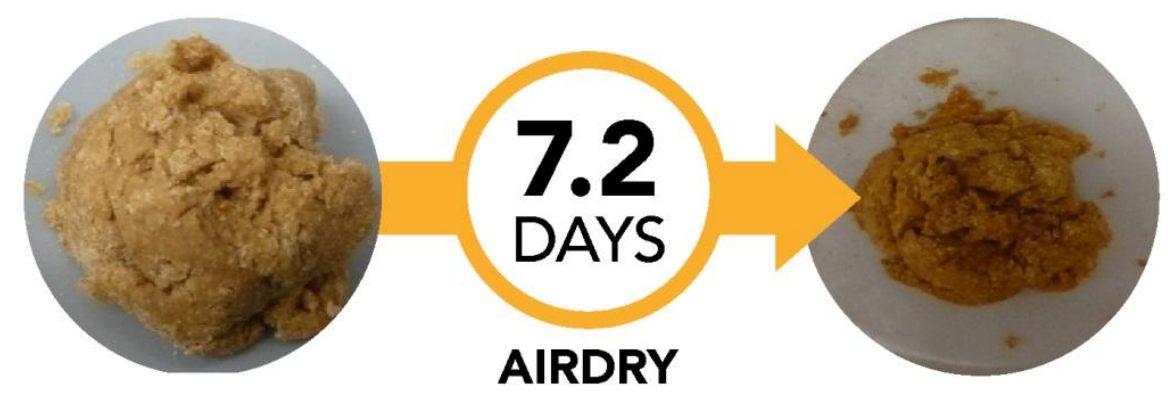

Figure 3. Effects of drying for 7.2 days on 3:1 vol ratio mixture of $3.5 \mathrm{M} \mathrm{HNO}_{3}$ and dried sWheat.

\section{Results and Discussion}

According to the CCPS, the chemical reactivity hazards of any chemical system depend on 1) the potential energy of any chemical reactions that can occur between constituents, 2) the rates of any potential reactions and/or their decompositions, and 3) the process equipment. For a reactive waste chemical system to be safe, the engineered system must be able to adequately exhaust any gases produced and dissipate any reaction heat to prevent temperatures from rising to the level where the chemical reaction rate(s) produce heat faster than the engineered system can dissipate the heat [17]. 
The important factors identified by the CCPS affecting chemical stability include temperature, the nature and concentrations of the reactants, the nature and concentrations of impurities or other compounds present, solvent, air when airsensitive compounds are present, and confinement. Temperature controls the chemical reaction rate with $a 0^{\circ} \mathrm{C}$ increase, in general, causing the reaction rate to increase by a factor between roughly 2 and 4 . The reactants determine the susceptibility to reaction through their functional group(s), the possible potential energies, and the potential to produce gaseous products. Systems meriting consideration or designated as incompatible include mixtures of organics and oxidizers other than oxygen, such as nitrates and nitrites. Reaction rate at a given temperature is roughly proportional to the reactants' concentrations. Impurities can have catalytic effects by reducing the activation energy $E_{a}$, increasing reaction rate, and reducing onset temperatures. Solvents may serve as a facilitating conveyance for reactants, as diluents, and as heat sinks. Confinement may cause the reaction rate to increase due to pressure increases or by preventing reactive product gases from escaping so that they might participate in secondary reactions [17].

\subsection{Thermal Behavior of sWheat}

To identify the reactions of the nitrate waste constituents with sWheat, the baseline thermal behavior must be known. We used TG/DTA to characterize sWheat's thermal sensitivities.

Shewry et al. [33] and Sramkova, Gregova, and Sturdik [34] report that wheat kernels are composed by mass of $13 \%$ to $15 \%$ bran or outer shell, $80 \%$ to $85 \%$ endosperm, and $2 \%$ to $3 \%$ germ. The bran is a complex mix of cellulose, lignin, pentosans, and polymers based on xylose and arabinose, which are tightly bound to proteins. The endosperm is nominally $83 \%$ starch, $13 \%$ proteins and enzymes, $1.5 \%$ 
fats, $1.5 \%$ dietary fibers, and $0.5 \%$ minerals. Starch and proteins are the predominant kernel constituents at $65 \%$ to $70 \%$ and $14 \%$, respectively.

Pure cellulose, a major component of sWheat, exhibits a variety of thermal decomposition behaviors depending on whether the decomposition gases are prevented from escaping [35-41]. If confined or partially confined under anaerobic conditions, the decomposition of cellulose starts near $200^{\circ} \mathrm{C}$ and is exothermic [38, 41]. If unconfined under anaerobic conditions, the decomposition is endothermic [3840]. When heated in air, cellulose burns exothermically above $310^{\circ} \mathrm{C}[42,43]$. The TG/DTA output in Figure 4 shows that undried sWheat heated in Ar at $5^{\circ} \mathrm{C} /$ min immediately began a $10 \%$ endothermic mass loss that was likely water evaporation given the water retention properties of sWheat [31], the affinity of glucosidic materials for water, and the molecular distribution of water across the glucose polymer [44]. Upon completion of this first reaction, the sWheat lost another $65 \%$ through a series of endothermic mass losses. In air, the same initial endothermic mass loss occurred, followed by a series of exothermic reactions that began near $150^{\circ} \mathrm{C}$ and resulted in little residual mass when heated to $520^{\circ} \mathrm{C}$. 


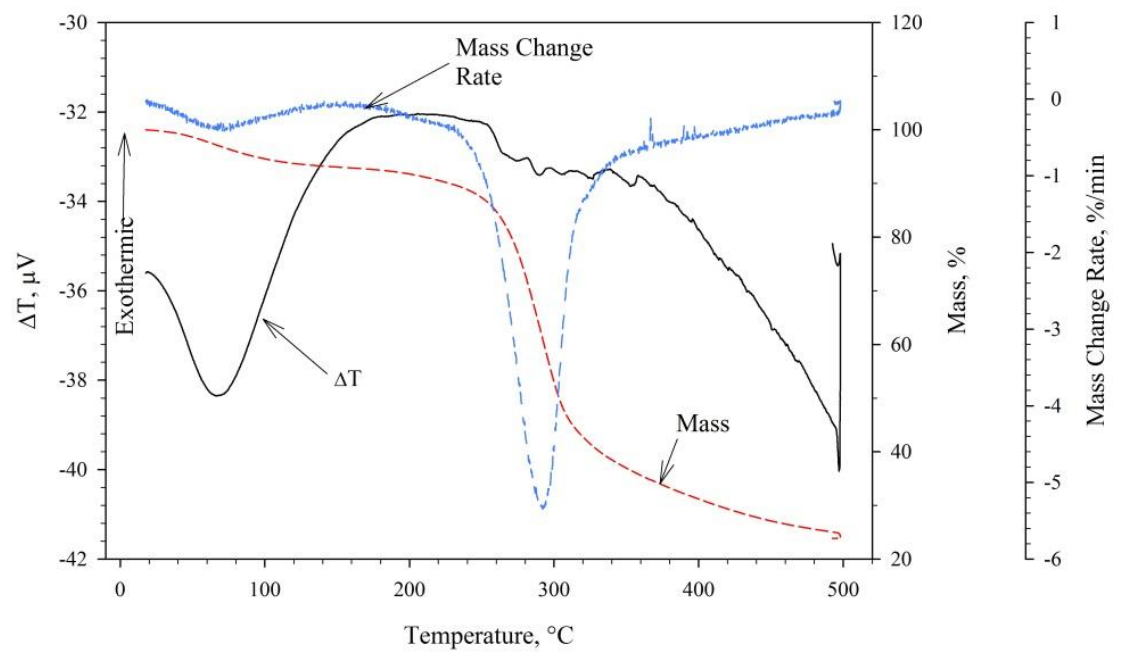

Figure 4. Thermal behavior of undried sWheat in Ar as measured by TG/DTA at

\section{$5^{\circ} \mathrm{C} / \mathrm{min}$}

\subsection{Thermal Behavior of $3.5 \mathrm{M} \mathrm{HNO}_{3} / \mathrm{s}$ Wheat}

The TG/DTA (Figure 5) found that $3.5 \mathrm{M} \mathrm{HNO}_{3} / \mathrm{sWheat}$ dried for $3 \mathrm{~h}$ at $20^{\circ} \mathrm{C}$ in flowing Ar immediately began the expected endothermic mass loss likely due to water and possibly $\mathrm{HNO}_{3}$ evaporation. While still losing water, the $\mathrm{HNO}_{3}$ and sWheat began a rapid exothermic reaction near $110^{\circ} \mathrm{C}$, which continued to $140^{\circ} \mathrm{C}$. This reaction was followed by a slower exothermic reaction that continued to $500^{\circ} \mathrm{C}$.

Applying the CCPS's $100^{\circ} \mathrm{C}$ rule-of-thumb safety margin for TG/DTA [17], $\mathrm{HNO}_{3} / \mathrm{sWheat}$ mixtures are likely susceptible to room-temperature exothermic reactions, as confirmed by ARC-testing. Normally, if the TG/DTA results indicated that exothermic reactions occurred at operational temperatures, further testing using more sensitive methods such as ARC would then be conducted to further refine acceptable operating conditions. 


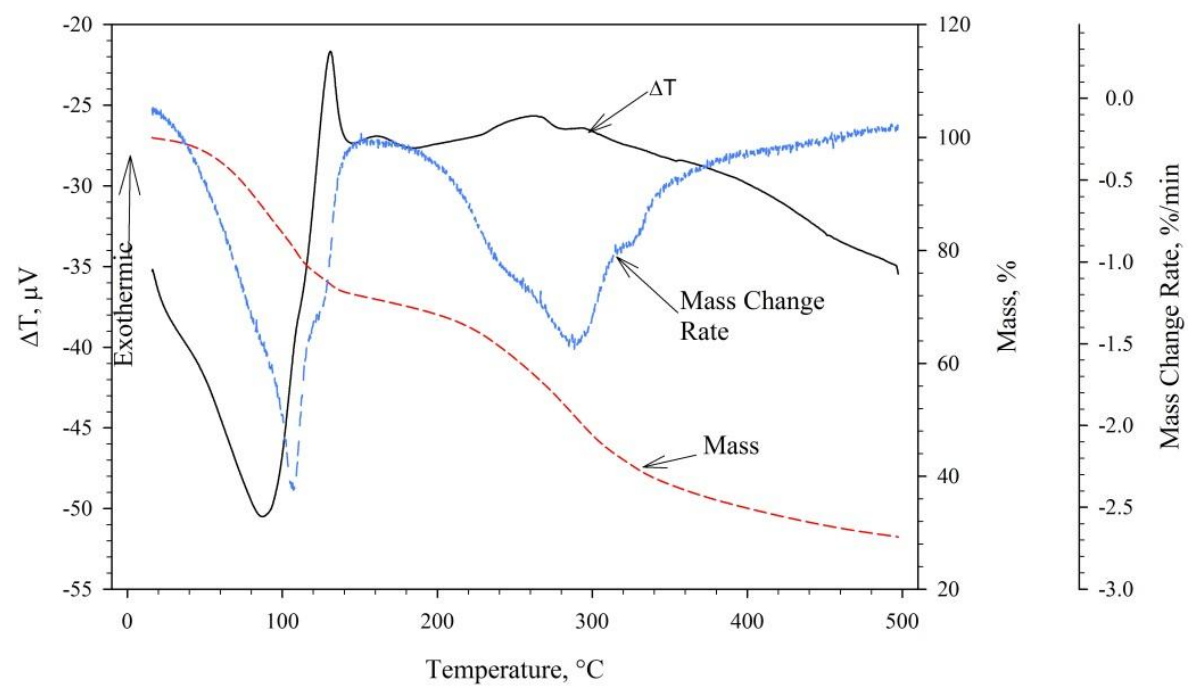

\section{Figure 5. TG/DTA-measured behavior of 3.5 $\mathrm{M} \mathrm{HNO}_{3} / \mathrm{sWheat} \mathrm{in} \mathrm{Ar} \mathrm{at} 5^{\circ} \mathrm{C} / \mathrm{min}$. Sample dried $3 \mathrm{~h}$ at $20^{\circ} \mathrm{C}$ in flowing Ar.}

Figure 6 illustrates how water as a significant heat sink affects reaction propagation. Undried $\mathrm{HNO}_{3} / \mathrm{sWheat}$ began a self-sustaining exothermic reaction in the ARC immediately at $30^{\circ} \mathrm{C}$ that sustained itself until $35^{\circ} \mathrm{C}$, whereupon the self-heat rate fell below the exotherm criteria. Raising the temperature to $50^{\circ} \mathrm{C}$ restarted a selfsustaining exothermic reaction that lasted to $90^{\circ} \mathrm{C}$, at which point the liquid evaporation heat consumption rate again exceeded the heat production rate. It is important to recognize that the chemical reaction itself does not stop at a particular temperature, but instead continues until one or both of the reactants are consumed. Subsequent heating to $120^{\circ} \mathrm{C}$ initiated a self-heating reaction that accelerated to $160^{\circ} \mathrm{C}$, after which the heat production rate slowed until the experiment was stopped at $190^{\circ} \mathrm{C}$.

We postulate that the heat production rates for the initial and later short-lived exothermic reaction(s) between $\mathrm{HNO}_{3}$ and $\mathrm{sWheat}$ were lower than the heat consumption rates for the endothermic evaporation of water $\left(\Delta \mathrm{H}_{\mathrm{vap}}=40.66 \mathrm{~kJ} / \mathrm{mol}\right)$ and nitric acid reactions. The dominance of the liquid evaporation reaction rates 
caused the ARC-observed self-heating rate to drop below the exotherm criteria (selfheat rate of $\left.0.01^{\circ} \mathrm{C} / \mathrm{min}\right)$. The endothermic evaporation reactions will compete with the exothermic reactions until the liquids are completely converted to gases or the heat production rate exceeds that of the competing endothermic reactions. If the exothermic reaction is unable to overcome the competing endothermic reaction, gaps between observed exothermic events such as those that occur in Figure 6. This postulate is supported by experiments of dried materials discussed later.

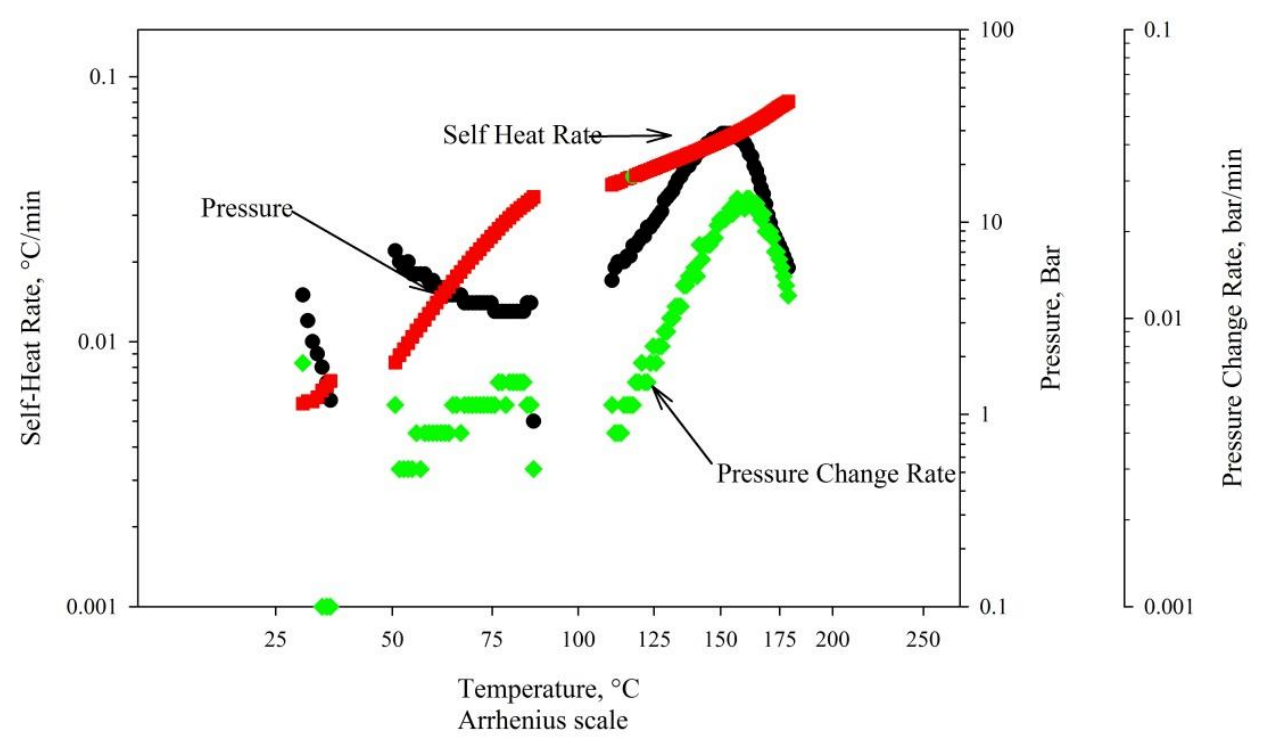

Figure 6. ARC-measured exothermic behavior of $2.8 \mathrm{~g}$ undried $3.5 \mathrm{M} \mathrm{HNO}_{3} / \mathrm{sWheat}$

These ARC and TG/DTA experiments using undried 3.5 M/sWheat indicate that 1) $\mathrm{HNO}_{3}$ and $\mathrm{sWheat}$ react exothermically near room temperature but the reactions are prevented from sustaining themselves by water evaporation and 2) that with drying over time the reactions can propagate. With respect to $\mathrm{HNO}_{3} / \mathrm{sWheat}$ waste in a vented drum, these low-temperature reactions in combination with the desiccating conditions of the salt mine will accelerate the drying, eventually permitting selfaccelerating reactions between $\mathrm{HNO}_{3} / \mathrm{sWheat}$, assuming ample reactants remain. 
In contrast to undried mixtures, when allowed to dry open to $20^{\circ} \mathrm{C}$ air, the lowtemperature exothermic reactions will self-heat the mixture to near $80^{\circ} \mathrm{C}$, when thermal runaway or ignition occurs as shown in Figure 7 or by Scheele, Minette, McNamara and Schwantes [45]. In these two ARC experiments, self-sustaining and accelerating reactions began immediately at $40^{\circ} \mathrm{C}$ and $30^{\circ} \mathrm{C}$, respectively. The samples slowly self-heated to $73^{\circ} \mathrm{C}$ and $78^{\circ} \mathrm{C}$, whereupon thermal runaway reactions or ignition occurred, rupturing the spherical titanium containers (see Figure 7). For the 16-h dried mixture, the last measured self-heat rate, pressure, and pressure change rate reached $40^{\circ} \mathrm{C} / \mathrm{min}, 12 \mathrm{bar}$, and $190 \mathrm{bar} / \mathrm{min}$ [45], respectively.

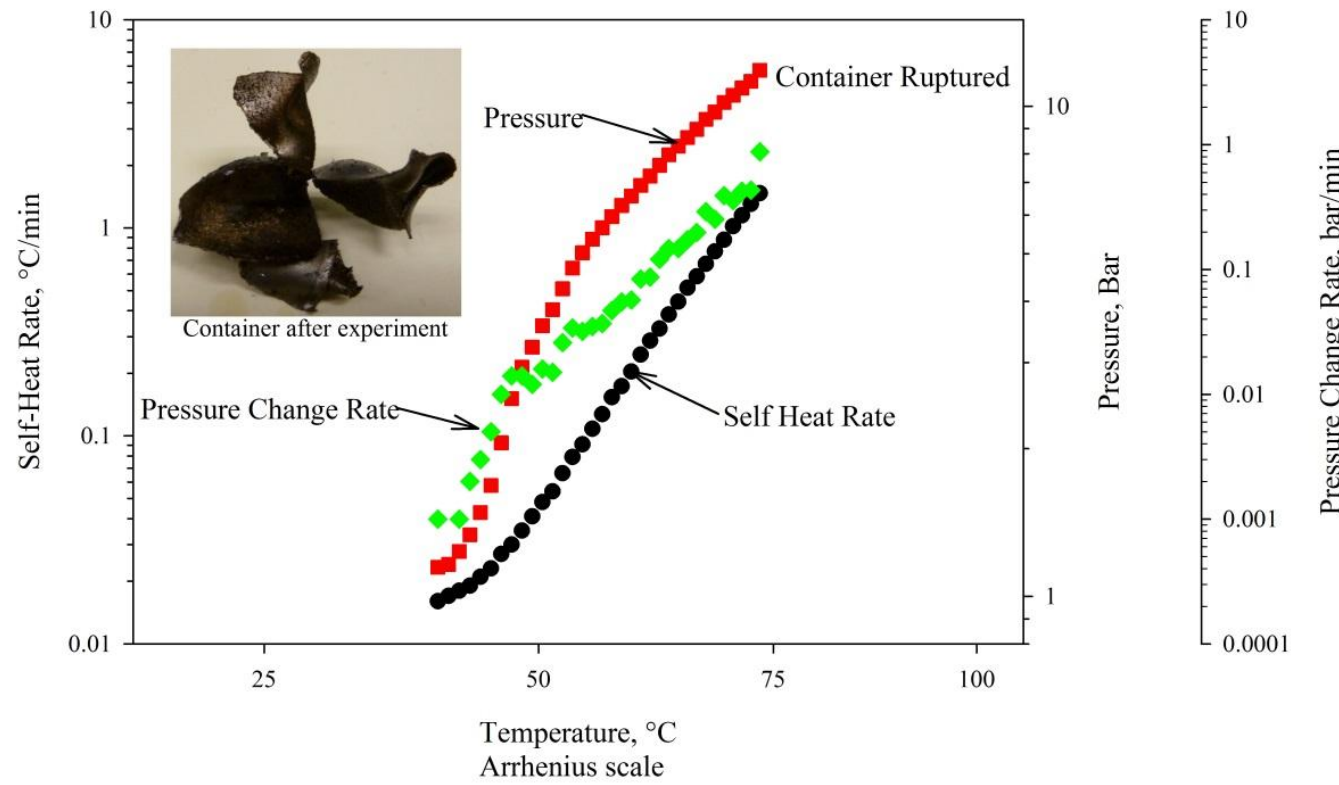

Figure 7. ARC-measured thermal behavior of 7.0 $\mathrm{g}$ of 7-day, air-dried saturated 3.5 $\mathrm{M} \mathrm{HNO}_{3} / \mathrm{sWheat}$ Inset provides picture of ruptured container.

These two ARC experiments indicate that $3.5 \mathrm{M} \mathrm{HNO}_{3} / \mathrm{sWheat}$ dried at room temperature will self-heat from room temperature to thermal runaway in a sealed system, and thus could explain the WIPP drum breach event. Some evaporative drying of the waste would be expected within a TRU waste drum since the drum is vented through a NucFil ${ }^{\circledR}$ drum vent filter and exposed to dry air [24]. 


\subsection{Thermal Behavior of $\left(0.3 \mathrm{M} \mathrm{Pb}_{\left.\left(\mathrm{NO}_{3}\right)_{2}-3.5 \mathrm{M} \mathrm{HNO}_{3}\right) / \mathrm{s} \text { Wheat }}\right.$}

Other waste constituents, such as $\mathrm{Pb}\left(\mathrm{NO}_{3}\right)_{2}$ from dissolution of the original $\mathrm{Pb}$ shielding, could react directly with the sWheat or catalyze or otherwise affect the thermal sensitivities of reactions between $\mathrm{HNO}_{3}$ and sWheat mixtures.

Comparison of Figure 8 with Figure 5 shows that an additional, lower-temperature exothermic reaction arises near $100^{\circ} \mathrm{C}$ (peak maximum $110^{\circ} \mathrm{C}$ ) when $0.3 \mathrm{M} \mathrm{Pb}\left(\mathrm{NO}_{3}\right)_{2}$ was present in $3.5 \mathrm{M} \mathrm{HNO}_{3}$. The exothermic reaction observed for the neat $3.5 \mathrm{M}$ $\mathrm{HNO}_{3}$ with sWheat with a peak maximum of $130^{\circ} \mathrm{C}$ appears unchanged. This indicates that $\mathrm{Pb}\left(\mathrm{NO}_{3}\right)_{2}$ reacts with the sWheat at a lower temperature than pure $\mathrm{HNO}_{3}$, suggesting that the presence of $\mathrm{Pb}$ should make the mixture more thermally sensitive (lower onset temperature).

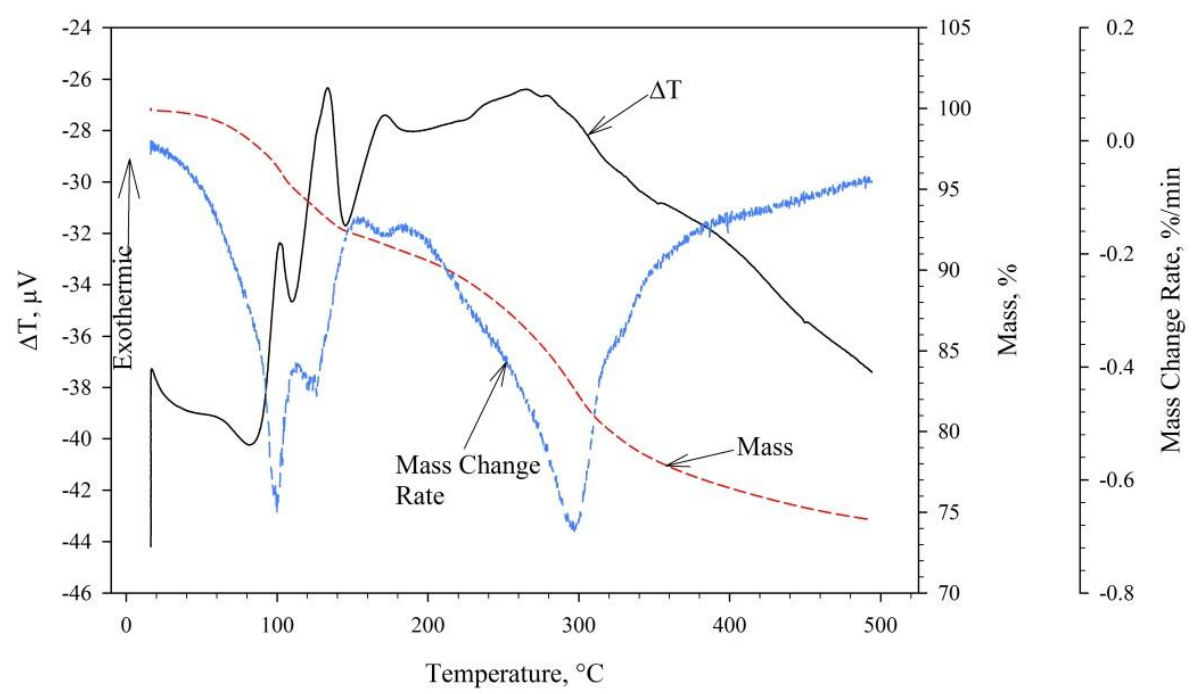

Figure 8. Thermal behavior of $(\mathrm{H}, \mathrm{Pb}) \mathrm{NO}_{3} / \mathrm{sWheat}$ in $\mathrm{Ar}$ as measured by TG/DTA at $5^{\circ} \mathrm{C} / \mathrm{min}$. Dried for $4 \mathrm{~h}$ at $20^{\circ} \mathrm{C}$ in $\mathrm{Ar}$.

\subsection{Thermal Behavior of Remediated Liquid Waste}

The other major potentially reactive waste constituent in the WIPP drum that breached was the TEA-neutralized nitric acid solution sorbed onto sWheat. Metal complexes of TEA exhibit variable thermal stabilities, with some exhibiting 
"explosive" properties when heated to elevated temperatures. Using DTA and TGA at a heating rate of $10^{\circ} \mathrm{C} / \mathrm{min}$, Içbudak, Yilmaz, and Olmez [46] found that the TEA nitrate salts of $\mathrm{La}, \mathrm{Ce}(\mathrm{III})$, and $\mathrm{Nd}(\mathrm{II})$ decomposed "violently" in nitrogen. These decompositions began and ended at $198^{\circ} \mathrm{C}$ and $800^{\circ} \mathrm{C}, 195^{\circ} \mathrm{C}$ and $500^{\circ} \mathrm{C}$, and $255^{\circ} \mathrm{C}$ and $600^{\circ} \mathrm{C}$, respectively. The La salt decomposed to $\mathrm{La}_{5} \mathrm{O}_{7} \mathrm{NO}_{3}$. The $\mathrm{Ce}(\mathrm{III})$ and $\mathrm{Nd}$ (II) salts decomposed in air to $\mathrm{CeO}_{2}$ and $\mathrm{Nd}_{2} \mathrm{O}_{3}$, with similar thermal behaviors. HTEAN melts at $80^{\circ} \mathrm{C}$ and is reported to begin exothermic (heat-producing) decomposition with the release of gaseous products at $250^{\circ} \mathrm{C}$ to $325^{\circ} \mathrm{C}$ when heated at $175^{\circ} \mathrm{C} \mathrm{s}^{-1}$ under 1380 bar (1380 kPa) of $\mathrm{Ar}$ [47]. Gases released included $\mathrm{CO}_{2}, \mathrm{~N}_{2} \mathrm{O}$, $\mathrm{CO}, \mathrm{NO}, \mathrm{NH}_{3}$, and $\mathrm{HCN}$. The gaseous nitrogen oxides can react with the fuel constituents in the waste mixture and the nitrogen oxide oxidants can react with the fuel gases $\mathrm{CO}, \mathrm{NH}_{3}$, and $\mathrm{HCN}$. Thus, protonation of TEA to produce HTEAN results in a more thermally unstable chemical compound that will decompose violently, producing gases that could participate in secondary exothermic reactions.

\subsubsection{Thermal behavior of HTEAN, $(\mathrm{H}, \mathrm{Pb}) \mathrm{TEAN},(\mathrm{H}, \mathrm{Pb}, \mathrm{Fe}) \mathrm{TEAN}$}

The TG/DTA found that HTEAN dried at $40^{\circ} \mathrm{C}$ for $2 \mathrm{~h}$ in $\mathrm{Ar}$ begins to decompose exothermically starting near $220^{\circ} \mathrm{C}$, as shown in Figure 9. Its decomposition was violently exothermic, as indicated by the rapid mass increase caused by the rapid production of gases, forcing the TG to register a very rapid mass increase and a subsequent ejection of sample. 


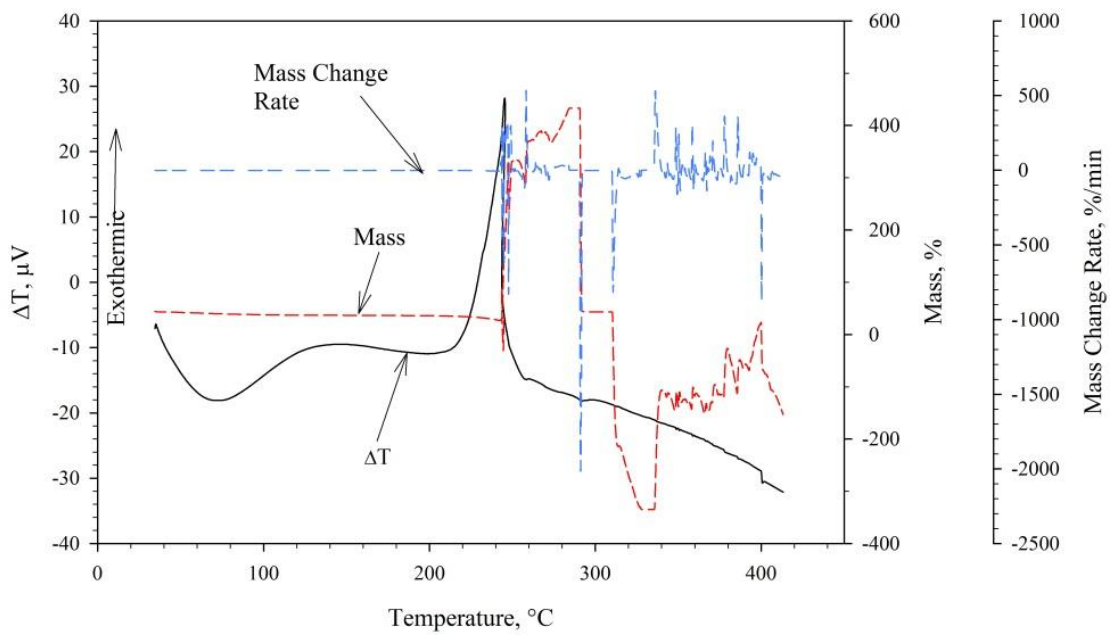

Figure 9. Thermal behavior of HTEAN as measured by TG/DTA at $5^{\circ} \mathrm{C} / \mathrm{min}$ in Ar. Dried at $35^{\circ} \mathrm{C}$ for $2 \mathrm{~h}$ in $\mathrm{Ar}$.

In the TG/DTA experiment shown in Figure 10, the TEA-neutralized $0.3 \mathrm{M}$ $\mathrm{Pb}\left(\mathrm{NO}_{3}\right)_{2} / 3.5 \mathrm{M} \mathrm{HNO}_{3}$ was prepared in the sample pan, dried in the TG/DTA for 5 min at $25^{\circ} \mathrm{C}$, heated to $55^{\circ} \mathrm{C}$ at $10^{\circ} \mathrm{C} / \mathrm{min}$, and isothermally dried for $50 \mathrm{~min}$. This $(\mathrm{H}, \mathrm{Pb}) \mathrm{TEAN}$ exhibited violent reactivity at high temperatures similar to HTEAN, but was accompanied by a series of additional, low-temperature exothermic mass loss reactions between $20^{\circ} \mathrm{C}$ and $40^{\circ} \mathrm{C}$. The TG/DTA observed a series of exothermic reactions beginning near $230^{\circ} \mathrm{C}$ that culminated in a rapid exothermic mass loss and ejection starting at $240^{\circ} \mathrm{C}$. Figure 11 provides a picture of the ejected $(\mathrm{H}, \mathrm{Pb}) \mathrm{TEAN}$ thermal decomposition product and sample pan which illustrates rapid gas production. 


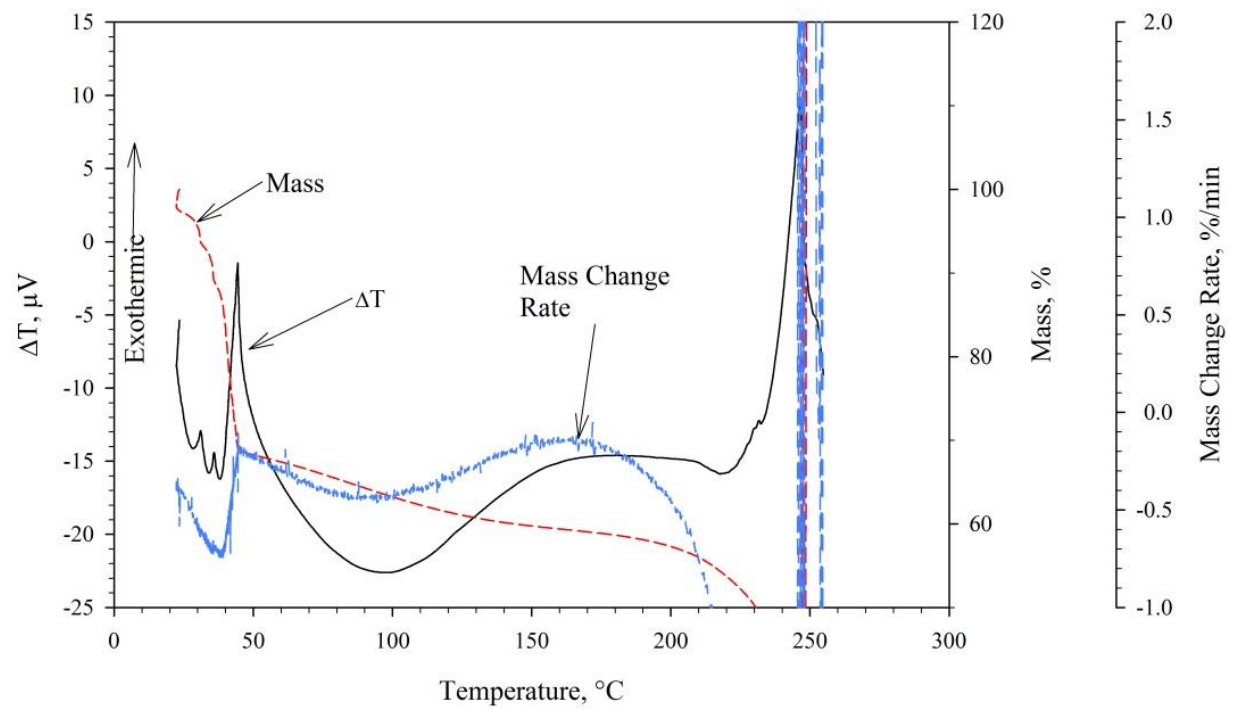

Figure 10. Thermal behavior of (H,Pb)TEAN as measured by TG/DTA 1) dried for 5 minutes at $25^{\circ} \mathrm{C}, 2$ ) heated to $55^{\circ} \mathrm{C}$ at $10^{\circ} \mathrm{C} / \mathrm{min}$ and dried for $50 \mathrm{~min}$, and 3 ) heated at $5^{\circ} \mathrm{C} / \mathrm{min}$ in $\mathrm{Ar}$ ).

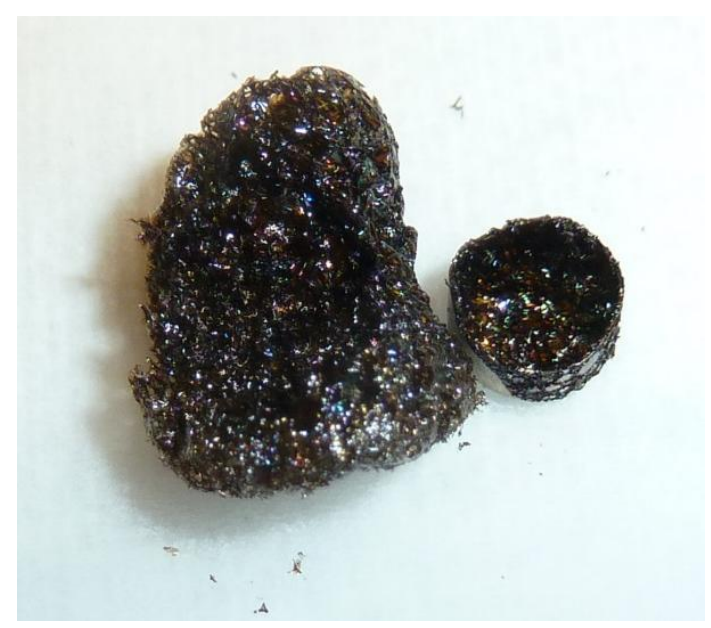

\section{Figure 11. (H,Pb)TEAN thermal decomposition product}

The $(\mathrm{H}, \mathrm{Pb}, \mathrm{Fe}) \mathrm{TEAN}$ for the ARC test was prepared in two stages by adding near equal amounts of the TEAN solution to the ARC container. The first addition was dried for 3 days at $40^{\circ} \mathrm{C}$ and the second plus first addition was dried for two days at room temperature and then dried for $2 \mathrm{~h}$ at $40^{\circ} \mathrm{C}$ to $50^{\circ} \mathrm{C}$ in an Ar-dry box, but did not fully dry.

The ARC analysis of $3.4 \mathrm{~g}$ of dried $(\mathrm{H}, \mathrm{Pb}, \mathrm{Fe})$ TEAN provided in Figure 12 shows that below $100^{\circ} \mathrm{C}$, the $\mathrm{ARC}$ observed several unsustainable exotherms with self- 
heating rates exceeding $0.01^{\circ} \mathrm{C} / \mathrm{min}$ after each $10^{\circ} \mathrm{C}$ step increase; however, immediately after identification of exothermic behavior, the self-heating rate fell to negative rates, resulting in only the pressure and pressure change rate being presented. The absence of observed, sustainable, low-temperature reactivity could be a result of the presence of volatile liquids. Once dry, a self-accelerating exothermic reaction began at $130^{\circ} \mathrm{C}$ and continued to $215^{\circ} \mathrm{C}$, when the gas production and self-heating rate accelerated, leading to a ruptured container. The last recorded self-heat rate, pressure, and pressure change rate were $100^{\circ} \mathrm{C} / \mathrm{min}, 210 \mathrm{bar}$, and $6000 \mathrm{bar} / \mathrm{min}$, respectively, which indicate a very energetic and fast gas-producing reaction.

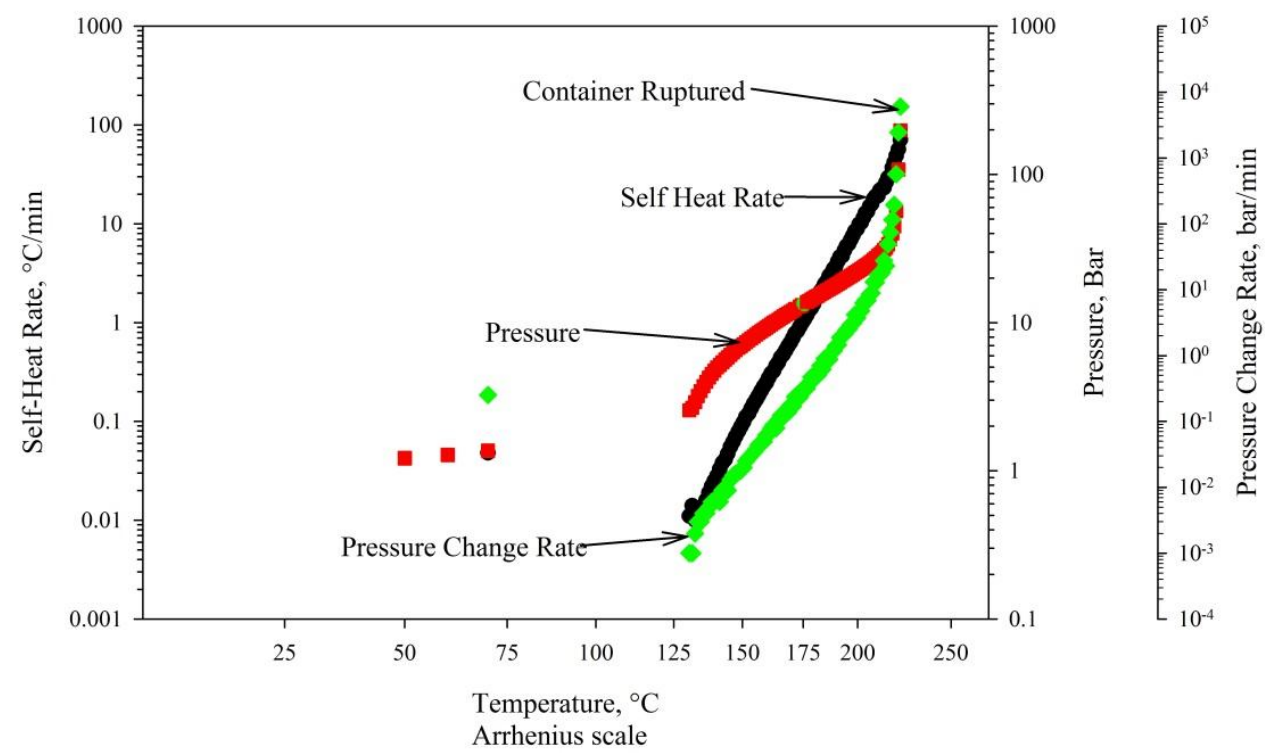

Figure 12. ARC-measured exothermic behavior of $3.4 \mathrm{~g}$ semi-dried $(\mathrm{H}, \mathrm{Pb}, \mathrm{Fe}) \mathrm{TEAN}$ prepared in two stages, with the first addition dried for 3 days at $40^{\circ} \mathrm{C}$ and the combined second and first dried 2 days at room temperature and $2 \mathrm{~h}$ at $40^{\circ} \mathrm{C}$ to $50^{\circ} \mathrm{C}$ in an Ar-dry box.

\subsubsection{Reactivity of $(\mathrm{H}, \mathrm{M}) \mathrm{TEAN} / \mathrm{sWheat}$}

After neutralization in the remediation process, the liquid fraction was solidified with sWheat. As shown in Figure 13, the TG/DTA of HTEAN/sWheat dried at $40^{\circ} \mathrm{C}$ in Ar found an exothermic mass loss between $95^{\circ} \mathrm{C}$ and $180^{\circ} \mathrm{C}$, followed immediately by a second, more significant exothermic mass loss. When heated in air at $5^{\circ} \mathrm{C} / \mathrm{min}$ after 
drying at $50^{\circ} \mathrm{C}$ in $\mathrm{Ar}$, the HTEAN/sWheat had a small exothermic reaction between $60^{\circ} \mathrm{C}$ and $95^{\circ} \mathrm{C}$, followed immediately by a weak exotherm to $180^{\circ} \mathrm{C}$, which was followed by a series of significant exothermic mass loss reactions.

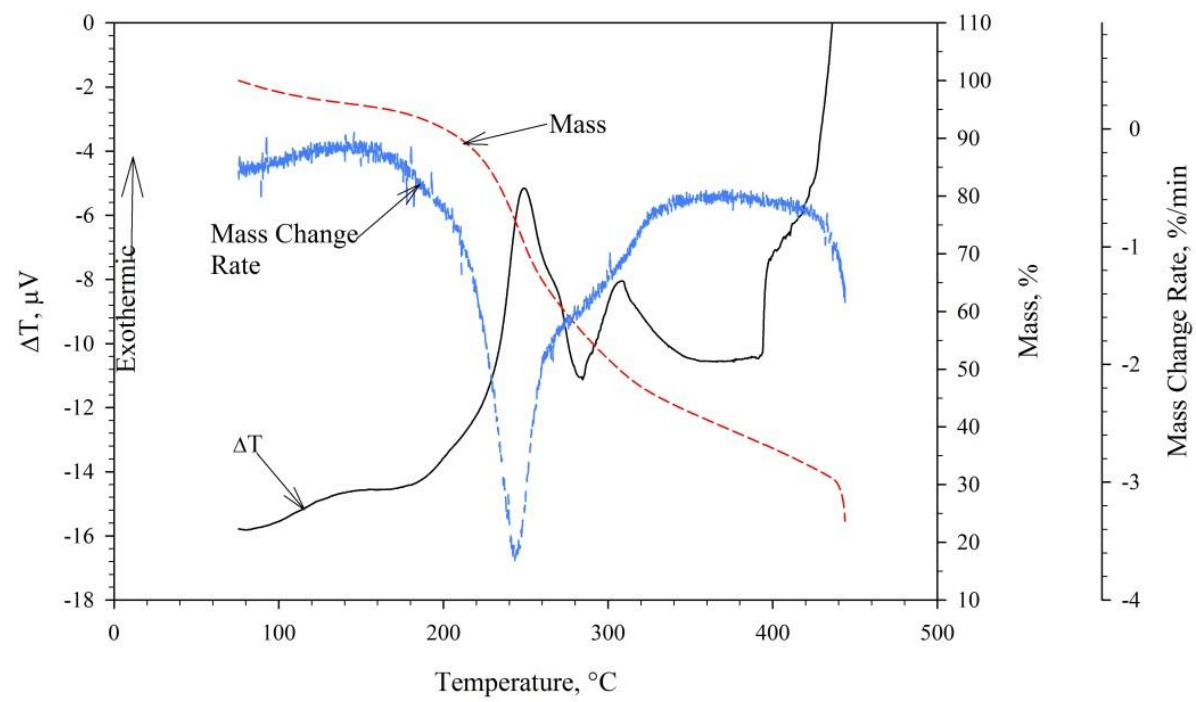

Figure 13. Thermal behavior of HTEAN/sWheat in Ar as measured by TG/DTA at $5^{\circ} \mathrm{C} / \mathrm{min}$. Sample dried at $40^{\circ} \mathrm{C}$ in Ar for $2 \mathrm{~h}$.

The ARC found that undried HTEAN/sWheat began a self-accelerating exothermic reaction after being heated to $145^{\circ} \mathrm{C}$ (Figure 14). It is likely that the evaporation of water prevented the ARC from detecting the TG/DTA-observed HTEAN exothermic reactions below $100^{\circ} \mathrm{C}$ and the added thermal mass of sWheat delayed the onset of the $125^{\circ} \mathrm{C}$ HTEAN decomposition observed for $(\mathrm{H}, \mathrm{Pb}, \mathrm{Fe}) \mathrm{TEAN}$. 


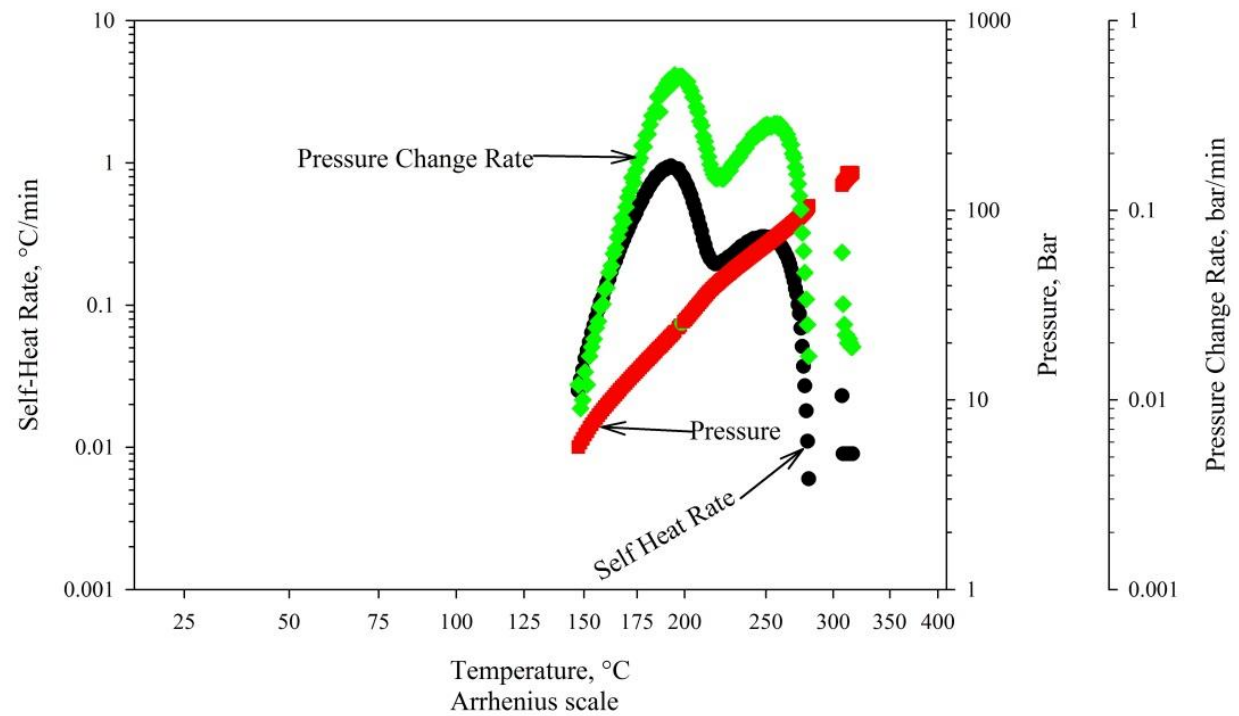

Figure 14. ARC-measured exothermic behavior of $2.8 \mathrm{~g}$ undried HTEAN/sWheat.

In contrast to undried HTEAN/sWheat, the ARC detected unsustainable exothermic reaction(s) for the same amount of $(\mathrm{H}, \mathrm{Pb}) \mathrm{TEAN} / \mathrm{sWheat}$ near $35^{\circ} \mathrm{C}$ (Figure 15). This suggests that the addition of $\mathrm{Pb}$ heightens the thermal sensitivity of TEAN/sWheat. The significant self-accelerating reaction began near the same temperature of $145^{\circ} \mathrm{C}$.

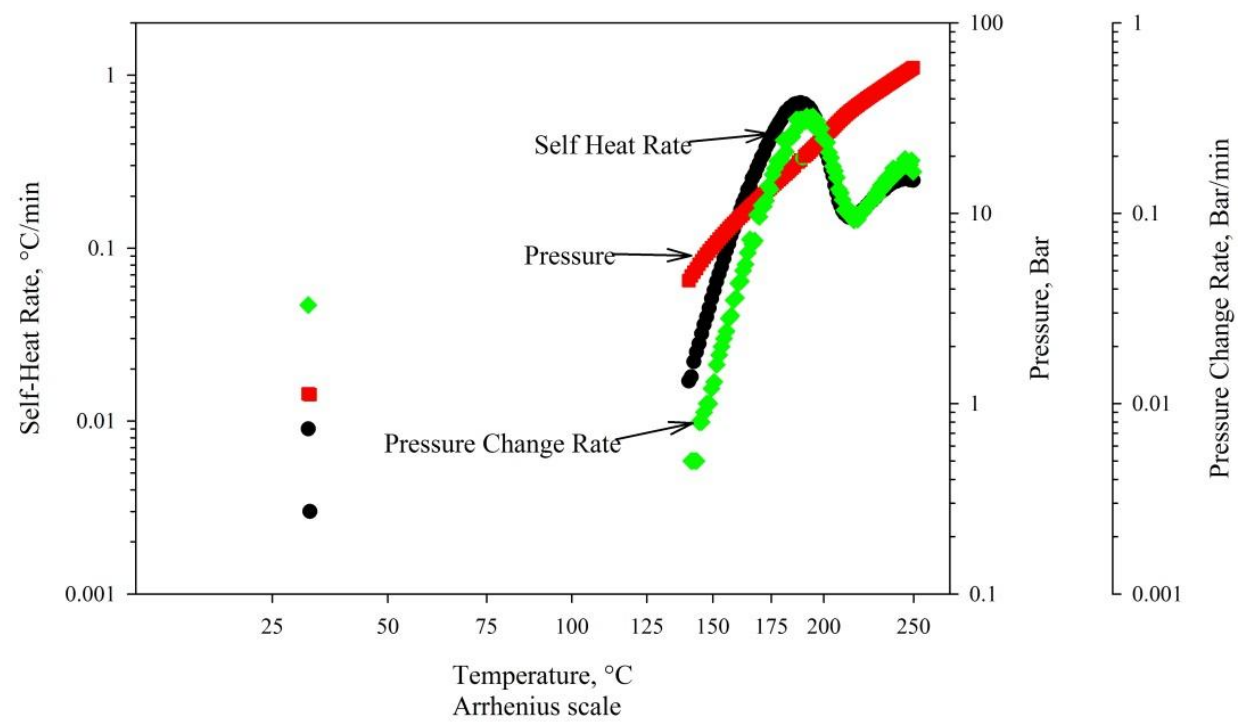

Figure 15. ARC-measured exothermic behavior of $2.8 \mathrm{~g}$ undried (H,Pb)TEAN/sWheat. 
Comparison of Figure 8 and Figure 9 with Figure 16 shows that, in contrast to the neat hydrogen or metal TEANs, when mixed with the sWheat, the added thermal mass of sWheat prevents the TG/DTA-measured $220^{\circ} \mathrm{C}$ violent decomposition of the neat $(\mathrm{H}, \mathrm{M}) \mathrm{TEANs}$. The oxidation of the sWheat with its significant DTA peak at $300^{\circ} \mathrm{C}$ confounds the interpretation of the TG/DTA analysis, but it is likely that the two sharp DTA peaks were due to TEAN decomposition.

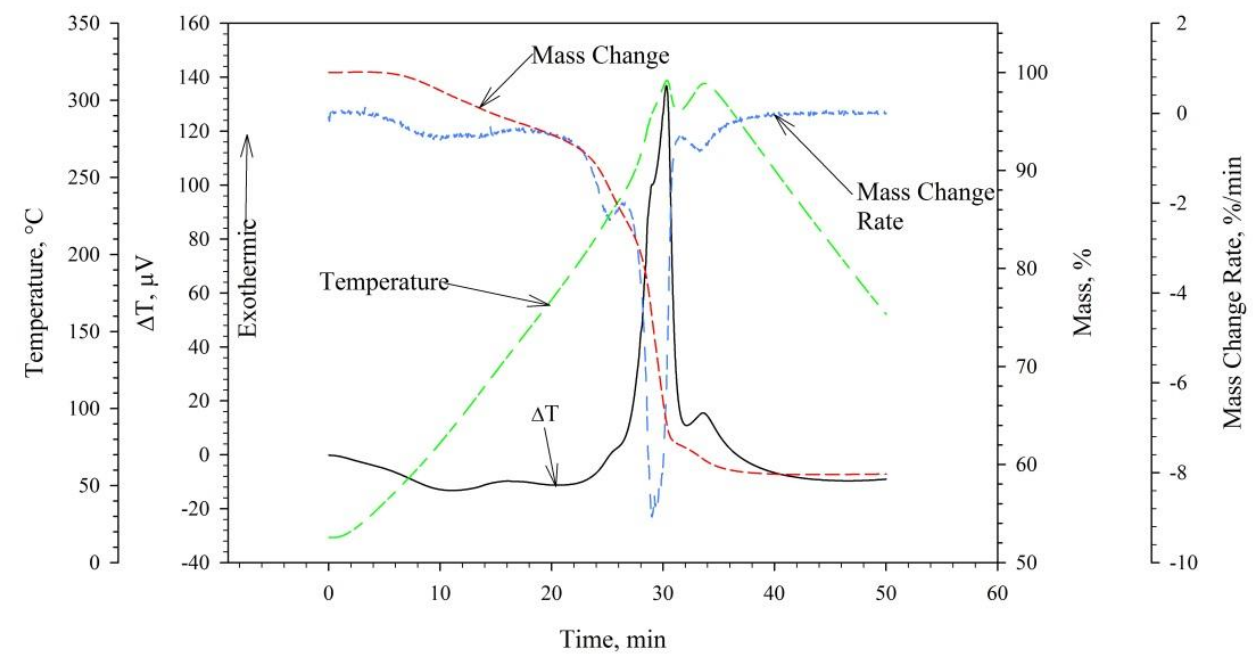

Figure 16. TG/DTA-measured thermal behavior of partially dried $(\mathrm{H}, \mathrm{Pb}, \mathrm{Fe}) \mathrm{TEAN} / \mathrm{sWheat}$ in air at $10^{\circ} \mathrm{C} / \mathrm{min}$ as function of time. Sample dried for 11 days at room temperature in air.

For a $(\mathrm{H}, \mathrm{Pb}, \mathrm{Fe}) \mathrm{TEAN}$ mixture partially dried at $50^{\circ} \mathrm{C}$ for $5.5 \mathrm{~h}$, the $\mathrm{ARC}$ observed several unsustainable, low-temperature exotherms below $125^{\circ} \mathrm{C}$ (Figure 17), followed by a self-accelerating reaction beginning at $125^{\circ} \mathrm{C}$, which led to thermal runaway that ruptured the titanium sample container. The low-temperature reactions likely could not sustain themselves because the rate of heat production was less than the heat demands of water evaporation and heat dissipation of the sWheat. This lowtemperature reactivity suggests that when dry this TEAN, if not others, will support low-temperature self-accelerating reactions similar to the $\mathrm{HNO}_{3} / \mathrm{sWheat}$. Additional testing of dried $(\mathrm{H}, \mathrm{M})$ TEANs and sWheat is needed to determine if these waste 
constituents can sustain self-sustaining or accelerating reactions that are initiated near room temperature.

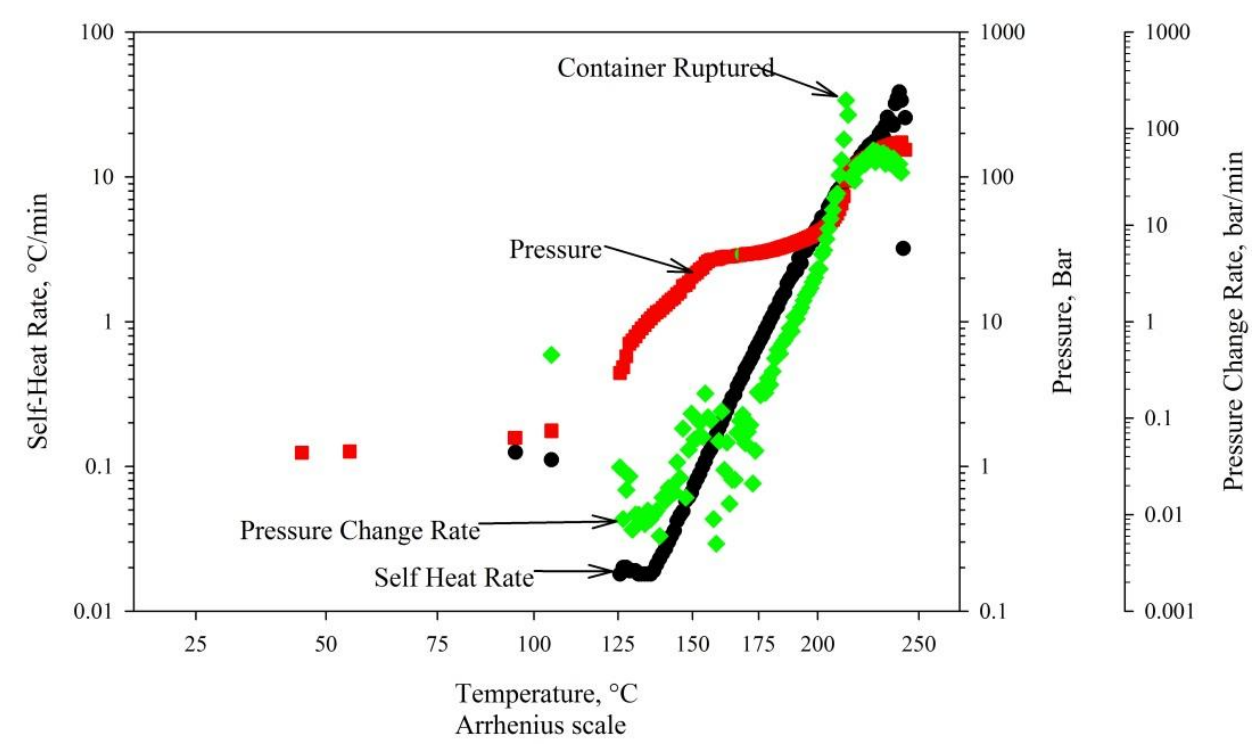

Figure 17. ARC-measured exothermic behavior of $9 \mathrm{~g}$ of $(\mathrm{H}, \mathrm{Pb}, \mathrm{Fe}) \mathrm{TEAN} / \mathrm{sWheat}$ dried at $50^{\circ} \mathrm{C}$ for $5.5 \mathrm{~h}$ in sample container.

\section{Summary and Conclusions}

Probative thermoanalytical studies investigating the reactivity of wheat-based pet litter mixed with acidic nitrates and/or hydrogen and metal complexes of TEA found that certain individual constituents and their mixtures are kinetically self-reactive at temperatures as low as room temperature. The room temperature-reactive dried mixtures self-heated under adiabatic and closed conditions to thermal runaway at $80^{\circ} \mathrm{C}$. Upon thermal runaway, sample sizes of a few grams of a solid mixture produced gases sufficient to exceed pressures of $20 \mathrm{MPa}$ (200 bar) and rupture a robust spherical reaction vessel fabricated from titanium metal. Water was found to quench and prevent self-propagation of low-temperature reactions. These results may help explain the cause of the drum breach in WIPP.

Specifically for the tested simulated waste constituents: 
- A mixture of 3.5 $\mathrm{M} \mathrm{HNO}_{3}$ and sWheat, if dry, can self-heat beginning between $30^{\circ} \mathrm{C}$ and $40^{\circ} \mathrm{C}$, and can self-heat under closed, adiabatic conditions to an $80^{\circ} \mathrm{C}$ energetic, rapid, gas-producing thermal runaway.

- Addition of lead nitrate to $3.5 \mathrm{M} \mathrm{HNO}_{3}$ added an earlier initial onset reaction of nitrate with sWheat in TG/DTA testing, suggesting that metals in the waste can catalyze the reaction between nitrate and sWheat or other glucosodic materials.

- $(\mathrm{H}, \mathrm{M}) \mathrm{TEANs}$ begin to decompose (self-react) at temperatures between $125^{\circ} \mathrm{C}$ and $150^{\circ} \mathrm{C}$, producing heat and gases, and eventually decompose violently at temperatures over $200^{\circ} \mathrm{C}$ in TG/DTA tests.

- Mixtures of (H,M)TEANs and sWheat have similar decomposition onsets, but did not decompose violently in TG/DTA tests. However, further testing of dried mixtures is required to confirm the lack of violent decomposition.

- The presence of free or bound water in all of the systems studied here significantly affected the propagation of reactions observed by the ARC at temperatures below $100^{\circ} \mathrm{C}$.

Because of the limited scope and duration of our probative tests, these findings present an incomplete evaluation of the susceptibility of all possible $\mathrm{Pu}$-waste constituents to low-temperature thermal initiation. Additionally, ARC testing is recommended for waste constituents that exhibit exothermic reactions observed below $100^{\circ} \mathrm{C}$ by TG/DTA to more accurately evaluate self-heating and reactivity. Specifically, we recommend ARC testing of dried $(\mathrm{H}, \mathrm{Pb}, \mathrm{Fe}) \mathrm{TEAN} / \mathrm{sWheat}$, (H,M)TEAN, and (H,M)TEAN/sWheat. We also recommend testing using TG/DTA coupled with evolved gas analysis, ARC, and even larger-scale testing "cook-off" experiments to evaluate aging of remediated waste constituents. 
The breach of the WIPP drum, the past accident at the Rocky Flats Environmental Site, studies on potential decontamination wastes from the Plutonium Finishing Plant, and these studies illustrate the reactivity hazards of mixing a strong oxidant with fuel(s) and emphasize the importance of ensuring that TRU and other industrial wastes containing oxidants and fuels are stable at all expected environmental conditions during generation, interim storage, and transport, and over time following emplacement in a disposal facility. To avoid potential reactivity hazards at DOE licensed nuclear disposal facilities, wheat-based pet litter should not be used to solidify and stabilize acidic nitrates. Our studies hint that the use of TEA commercially to neutralize nitric acid solutions of metal nitrate salts should be carefully considered, particularly if the wastes could dry.

\section{Acknowledgments}

We would like to thank VV Viswanathan for the use of his ARC, AM Casella for his technical review, DS Coffey for Quality Engineering support, and MS Wilburn for editing this article. This work was supported by the U.S. Department of Energy under Department of Energy Contract DE-AC05-76RL01830 and Contract DE-AC09-08SR22470. 


\section{References}

[1] D.L. Wilson, et al. 2015. Waste Isolation Pilot Plant Technical Assessment Team Report. SRNL-RP-2014-01198, http://energy.gov/sites/prod/files/2015/03/f20/MARCH\%202015\%20\%20FINAL\%20TECHNICAL\%20ASSESSMENT\%20TEAM\%20REPORT.pdf, Savannah River National Laboratory, Aiken, South Carolina.

[2] U.S. Department of Energy. 2014. Waste Isolation Pilot Plant Recovery Plan, Rev 0. http://www.wipp.energy.gov/Special/WIPP\%20Recovery\%20Plan.pdf. U. S. Department of Energy, Washington, D.C.

[3] C.L. Beyler. 2004. Analysis of the Cause of the Fire in Glovebox 8, Room 2325, Building 371 at RFETS on 6 May 2003. HAI Project 1042-006. Hughes Associates, Inc, Baltimore, Maryland.

[4] C.L. Beyler, et al., Ignition studies of cerium nitrate treated towels, Fire and Materials, 30 (2006) 223-240.

[5] A.M. Hopkins, et al. 2005. Safety Studies to Measure Exothermic Reactions of Spent Plutonium Contamination Chemicals Using Wet and Dry Decontamination Methods. The 10th International Conference on Environmental Remediation and Radioactive Waste Management September 4-8, 2005, Scottish Exhibition \& Conference Centre, Glasgow, Scotland, http://www.osti.gov/scitech/servlets/purl/852223. American Society of Mechanical Engineers, Fairfield, New Jersey.

[6] J.R. Ewalt, et al. 2005. Treatability Studies Used to Test for Exothermic Reactions of Plutonium Decontamination Chemicals. HNF-25630-FP, Rev 0, Fluor Hanford, Richland, Washington.

[7] P.A. Scott, et al. 2006. Overview of Technologies and Innovations Being Developed for Fluor Hanford Projects at the Hanford Site. Waste Management 2006 Proceedings, Tucson, Arizona.

[8] R.D. Scheele, et al. 2005. Thermal Stability Studies of Candidate Decontamination Agents for Hanford's Plutonium Finishing Plant Plutonium-Contaminated Gloveboxes. PNNL-15410, http://www.pnl.gov/main/publications/external/technical_reports/PNNL15410.pdf, Pacific Northwest National Laboratory, Richland, Washington.

[9] A.M. Hopkins, et al. 2005. Safety Studies to Measure Exothermic Reactions of Spent Plutonium Contamination Chemicals Using Wet and Dry Decontamination Methods. The 10th International Conference on Environmental Remediation and Radioactive Waste Management http://www.iaea.org/inis/collection/NCLCollectionStore/_Public/37/001/37001522.pdf. American Society of Mechanical Engineers, Glasgow, Scotland.

[10] NPS Corporation, 2014. Kolorsafe Liquid Acid Neutralizer Safety Data Sheet Version 1.0, http://www.npscorp.com/assets/msds/kolorsafe-liquid-acid-neutralizerna030714final.pdf, Green Bay, Wisconsin

[11] Pet Care Systems, 2015, Swheat Scoop, http://www.swheatscoop.com/products/, Detroit Lakes, Minnesota

[12] Dow Chemical Company, 2014. Triethanolamine 99\% MSDS, http://www.dow.com/webapps/msds/ShowPDF.aspx?id=090003e8804bfd90, Midland, Michigan 
[13] Dow Chemical Company, 2016. DOW Triethanolamine - Technical Data Sheet, http://www.dow.com/scripts/litorder.asp?filepath=amines/pdfs/noreg/111-01412.pdf, Midland, Michigan

[14] A. Fowkes, W.T.A. Harrison, (Nitrato-[kappa]2O,O')bis(triethanolamine[kappa]4N,O,O',O")lanthanum(III) dinitrate, Acta Crystallographica Section C, 62 (2006) $\mathrm{m} 232-\mathrm{m} 233$.

[15] K. Neilsen, et al., The Crystal Structure of Di-triethanolamine-Ni(II)-dinitrate, Acta Chemica Scandinavica, 26 (1972) 889-896.

[16] F. Allen, The Cambridge Structural Database: a quarter of a million crystal structures and rising, Acta Crystallographica Section B, 58 (2002) 380-388.

[17] A.H. Heemskerk, et al., Guidelines for Chemical Reactivity Evaluation and Application to Process Design, American Institute of Chemical Engineers - Center for Chemical Process Safety, New York, 1995.

[18] R.W. Johnson, et al., Essential Practices for Managing Chemical Reactivity Hazards, American Institute of Chemical Engineers - Center for Chemical Process Safety, New York, 2003.

[19] D.L. Clark, D.J. Funk. 2015. Chemical Reactivity and Recommended Remediation Strategy for Los Alamos Remediated Nitrate Salt (RNS) Wastes. LA-UR-15-22393, http://permalink.lanl.gov/object/tr?what=info:lanl-repo/lareport/LA-UR-15-22393, Los Alamos National Laboratory, Los Alamos, New Mexico.

[20] R.D. Scheele, et al. 2008. Evaluation of Exothermic Reactions from Bulk-Vitrification Melter Feeds Containing Cellulose. PNNL-16677, Pacific Northwest National Laboratory, Richland, WA.

[21] R.D. Scheele, et al. 2008. Thermal Flammable Gas Production from Bulk Vitrification Feed. PNNL-17491, Pacific Northwest National Laboratory, Richland, Washington.

[22] R.D. Scheele, et al. 1995. Organic Tank Safety Project: Preliminary Results of Energetics and Thermal Behavior Studies of Model Organic Nitrate and/or Nitrite Mixtures and a Simulated Organic Waste. PNL-10213, Pacific Northwest Laboratory, Richland, Washington.

[23] D.L. Clark, D.J. Funk. 2015. Chemical Reactivity and Recommended Remediation Strategy for Los Alamos Remediated Nitrate Salt (RNS) Wastes. LA-UR-15-22393, http://permalink.lanl.gov/object/tr?what=info:lanl-repo/lareport/LA-UR-15-22393. Los Alamos National Labortory, Los Alamos, New Mexico.

[24] Nuclear Filter Technology, 2015, Hydrogen Diffusion Advanced Nucfil@-019 Drum Vent Filter, http://www.drcreatives.com/portfolio/nucfil/drum_vent.html, Golden, Colorado

[25] I. Barin, Thermochemical Data of Pure Substances, VCH, New York, 1989.

[26] D.I. Townsend, J.C. Tou, Thermal hazard evaluation by an accelerating rate calorimeter, Thermochimica Acta, 37 (1980) 1-30.

[27] J.C. Tou, L.F. Whiting, The thermokinetic performance of an accelerating rate calorimeter, Thermochimica Acta, 48 (1981) 21-42.

[28] P.E. Liley, et al. 1999. Physical and Chemical Data. Perry's Chemical Engineer's Handbook, 2, http://files.rushim.ru/books/spravochniki/Perrys-Chemical-Engineershandbook-1999.pdf, pp. 2-184. McGraw Hill, New York. 
[29] H.K. Ahn, et al., Determination of thermal properties of composting bulking materials, Bioresource Technology, 100 (2009) 3974-3981.

[30] NPS Corporation, 2014. Material Safety Data Sheet - Spilfter Products -Kolorsafe Liquid Acid Neutralizer MSDS No. 1006, Green Bay, Wisconsin

[31] J.H. Sladek, 1997. Method for Sorbing Liquid Using Ground Wheat Grain Litter. United States 5690052

[32] L.M. Ferris, Lead nitrate-nitric acid-water system, Journal of Chemical \& Engineering Data, 5 (1960) 242-242.

[33] P.R. Shewry, et al., Natural variation in grain composition of wheat and related cereals, Journal of Agricultural and Food Chemistry, 61 (2013) 8295-8303.

[34] Z. Sramkova, et al., Chemical composition and nutritional quality of wheat grain, Acta Chimica Slovaca, 2 (2009) 115-138.

[35] A. Raemy, M. Ottaway, The use of high pressure DTA, heat flow and adiabatic calorimetry to study exothermic reactions, Journal of Thermal Analysis, 37 (1991) 19651971.

[36] G. Várhegyi, et al., Kinetics of the thermal decomposition of cellulose in sealed vessels at elevated pressures. Effects of the presence of water on the reaction mechanism, Journal of Analytical and Applied Pyrolysis, 26 (1993) 159-174.

[37] K.-T. Wu, E. Zavarin, Thermal analysis of mixtures of nitrates and lignocellulosic materials, Thermochimica Acta, 107 (1986) 131-148.

[38] D.F. Arseneau, Competitive reactions in the thermal decomposition of cellulose, Canadian Journal of Chemistry, 49 (1971) 632-638.

[39] U.-J. Kim, et al., Thermal decomposition of native cellulose: Influence on crystallite size, Polymer Degradation and Stability, 95 (2010) 778-781.

[40] H. Yang, et al., Characteristics of hemicellulose, cellulose and lignin pyrolysis, Fuel, 86 (2007) 1781-1788.

[41] A. Raemy, T.F. Schweizer, Thermal behaviour of carbohydrates studied by heat flow calorimetry, Journal of Thermal Analysis, 28 (1983) 95-108.

[42] D. Dollimore, J.M. Hoath, The application of thermal analysis to the combustion of cellulose, Thermochimica Acta, 45 (1981) 87-102.

[43] D. Davies, et al., Ignition studies on cotton cellulose by DTA, Thermochimica Acta, 63 (1983) 351-362.

[44] T.F. Child, Pulsed n.m.r. study of molecular motion and environment of sorbed water on cellulose, Polymer, 13 (1972) 259-264.

[45] R.D. Scheele, et al. 2016. Thermochemical Reactivity Hazards of TRU Waste Constituents - 16075. Waste Management 2016. WM Symposia, Inc., Phoenix, Arizona.

[46] H. İçbudak, et al., Thermal decomposition behaviour of some trivalent transition and inner-transition metal complexes of triethanolamine, Thermochimica Acta, 289 (1996) 23-32. 
[47] J.T. Cronin, T.B. Brill, Thermal decomposition of energetic materials 29-The fast thermal decomposition characteristics of a multicomponent material: liquid gun propellant 1845, Combustion and Flame, 74 (1988) 81-89. 


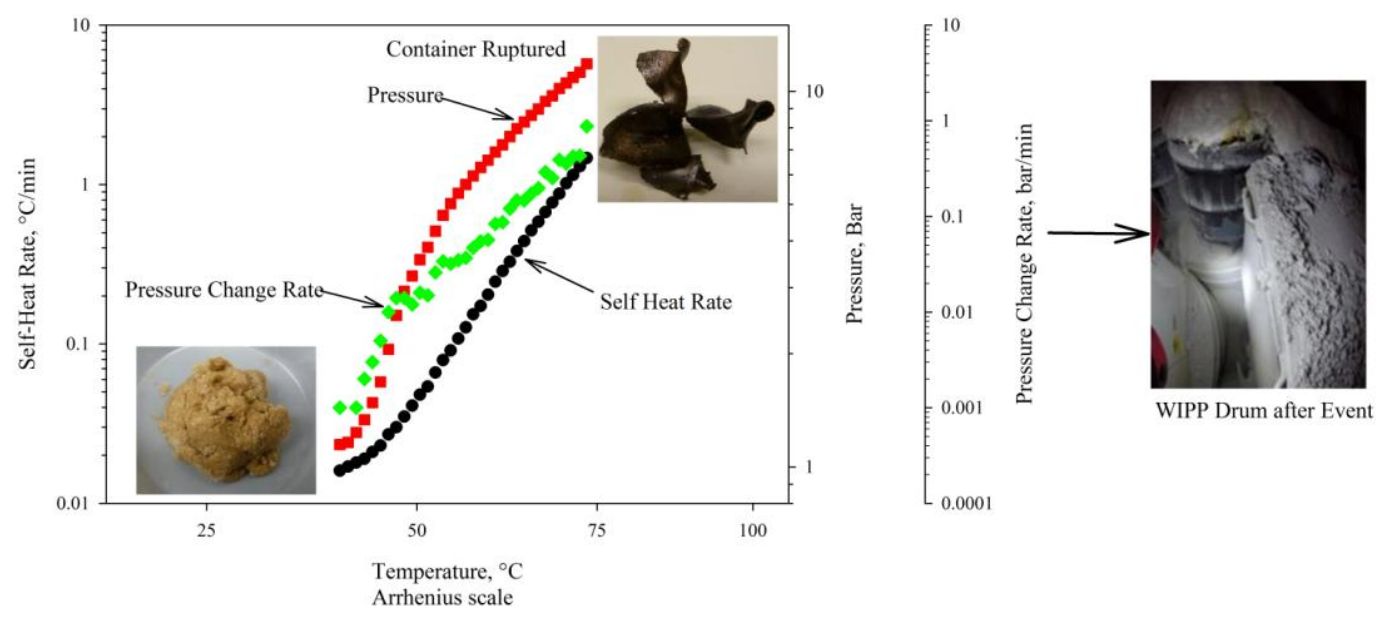

